Accepted Manuscript

Arbitrage risk and the cross-section of stock returns: Evidence from China

Yu En Lin, Chien Chi Chu, Akihiro Omura, Bin Li, Eduardo Roca

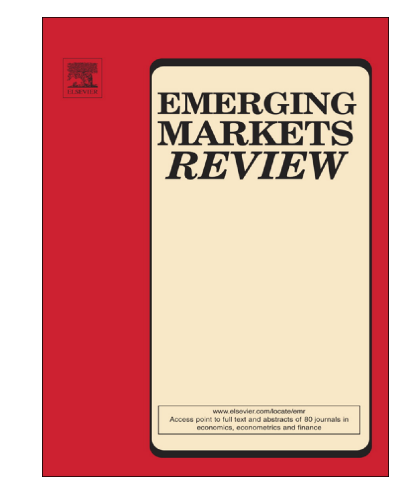

PII:

S1566-0141(18)30332-7

DOI: https://doi.org/10.1016/j.ememar.2019.03.007

Reference:

EMEMAR 609

To appear in:

Emerging Markets Review

Received date:

6 October 2018

Revised date:

15 March 2019

Accepted date:

26 March 2019

Please cite this article as: Y.E. Lin, C.C. Chu, A. Omura, et al., Arbitrage risk and the cross-section of stock returns: Evidence from China, Emerging Markets Review, https://doi.org/10.1016/j.ememar.2019.03.007

This is a PDF file of an unedited manuscript that has been accepted for publication. As a service to our customers we are providing this early version of the manuscript. The manuscript will undergo copyediting, typesetting, and review of the resulting proof before it is published in its final form. Please note that during the production process errors may be discovered which could affect the content, and all legal disclaimers that apply to the journal pertain. 


\section{Arbitrage Risk and the Cross-Section of Stock Returns: Evidence from}

\section{China}

Yu En Lin ${ }^{1}$, Chien Chi Chu ${ }^{2, *}$, Akihiro Omura ${ }^{3}, \mathrm{Bin} \mathrm{Li}^{4}$, Eduardo Roca ${ }^{5}$

${ }^{1}$ Business School, Jilin University, China

${ }^{2}$ Business School, Shantou University, China

${ }^{3}$ Graduate School of Business Administration, Meiji University, Japan

${ }^{4}$ Department of Accounting, Finance and Economics, Griffith University, Australia

${ }^{5}$ Department of Accounting, Finance and Economics, Griffith University, Australia

*Corresponding author. 


\begin{abstract}
We demonstrate that arbitrage risk, constructed using three measures — noise trader risk, trading cost and information uncertainty - can predict the return of stocks cross-sectionally in China. The findings are broadly consistent even when out-of-sample tests are conducted using the Fama-MacBeth cross-sectional regression approach. We also construct hypothetical portfolios using the information arising from arbitrage risk and find the existence of abnormal returns which is robust to the use of various portfolios constructed by re-sampling the observations through multiple approaches (e.g., by market capitalization and by book-to-market ratio). Lastly, we reconstruct our portfolios by considering the unique nature of the Chinese stock market (e.g., the dominance of individual investors). Our trading strategies again successfully obtain abnormal returns, suggesting that arbitrage risk can be useful to construct effective investment portfolios in China.
\end{abstract}

Keywords: Arbitrage Risk; Arbitrage Cost; Transaction Cost; Information Uncertainty; Out-of-Sample Forecast Returns 


\section{Introduction}

Following a rapid growth over the past few decades, China has become an important equity investment destination. As of 2017, the aggregate market capitalization of the companies listed on the three major exchanges in the country (i.e., the Shanghai Stock Exchange, Hong Kong Stock Exchange and Shenzhen Stock Exchange) is well over 10 trillion dollars. This equates to being second in the world after the New York Stock Exchange which has an overall market capitalization of more than 30 trillion dollars. However, as shown in Table 1, the Chinese market continues to possess a number of unique characteristics. One of these is in relation to the composition of investors. As can be seen in Table 1, the proportion of institutional investors' holding in China is a meager $4 \%$. Thus, individual investors remain dominant in the market. Given these unique characteristics, it is of great usefulness to investors and policymakers to understand whether the Chinese and other major markets share some common risk factors that drive stock prices. In addition, as the Chinese stock market has experienced multiple crashes in the recent decades (e.g., in October 2007 and June 2009), reducing the impact of systematic risks inherent in a constructed portfolio poses a great challenge to investors.

[Insert Table 1 here]

Arbitrage risk, explained as the risk arising from the volatility of arbitrage returns (Ali et al., 2003), has attracted attention from academics and investors in recent years. There is a large body of literature including Ali et al. (2003), Baker and Wurgler (2006) and Chou et al. (2013) showing that the existence of arbitrage risk leads to the emergence of anomalies. 
As anomalies are an important phenomenon for investors in order to potentially outperform the market and their peers, disentangling the information contained in arbitrage risk helps traders to make effective investment decisions. Most of the existing studies (e.g., Chou et al., 2013; Lam and Wei, 2011; Stambaugh et al., 2015; Ren, 2014), however, use such risk factor to explain the anomalies themselves. In this paper, we employ a relatively new concept of using arbitrage risk to predict stock returns and to construct investment portfolios in the Chinese stock market. Our study offers out-of-sample empirical evidence to help generalize the aforementioned idea.

The contributions of our study are threefold. Firstly, our findings can help investors to make effective investment decisions. Focusing on the Chinese market, our study examines the performance of portfolios constructed by reflecting the information embedded in arbitrage risk. The findings provide valuable information on whether profitable portfolios can be constructed in this fast-growing stock market using measures of arbitrage risk. To our knowledge, the study at hand is the first to implement the factors explored by the literature including Amihud (2002), Chou et al. (2013), Lam and Wei (2011) and Stambaugh et al. (2015) to construct portfolios in China. We further extend our analysis by restricting the number of stocks used to construct a portfolio and achieve similar results. This examination is valuable to individual investors who are not capable of building a portfolio which consists of a large number of stocks and those who often carry under-diversified portfolios (Goetzmann and Kumar, 2005; Meulbroek, 2005; Mitton and Vorkink, 2007).

Secondly, our study shows whether the impact of arbitrage risk on future stock returns is affected by the unique nature inherent in each stock market. Following the tests 
used by Lewellen (2015), we examine this arbitrage risk effect by focusing on the Chinese market which is growing rapidly yet still possessing the previously explained unique features. Our study thereby opens opportunities to extend the examinations of literature including Stambaugh et al. (2015) and Ali et al. (2003) to other emerging markets.

Thirdly, our study further contributes in generalizing the findings in the literature on arbitrage risk. Our sample covers a major transitional period of the Chinese stock market. Specifically, short-selling was not fully allowed in China until 2010. Considering the investor composition in China, the introduction of short-selling may amplify the effect of arbitrage risk. Taking this transitional period into account, our findings thereby provide valuable information on generalizing this notion on the dynamic relationship between arbitrage risk and future stock return. Nonetheless, our study differs from previous studies in a number of aspects. For example, while many of those studies attempt to disentangle the dynamics of stock price anomalies using the information of arbitrage risk (e.g., Ali et al., 2003; Chou et al., 2013), our study examines whether the arbitrage risk itself can be used to exploit abnormal returns.

Using data covering the period 2003-2016, we find that arbitrage risk, represented by noise trader risk, trading cost and information uncertainty, helps to predict the cross-sectional variation of stock returns in China. We obtain the value of adjusted $R$-squared close to $30 \%$, at the highest. This is considerably higher than that of the studies conducted on the U.S. market incorporating only the conventional firm characteristic measures (see Lewellen, 2015). In addition, in the portfolios constructed from the out-of-sample forecast returns, the strategy which uses noise trader risk and transaction costs obtains abnormal 
returns close to $1 \%$ even when we tested against the five factors in Fama and French (2015) ${ }^{1}$. Further, as a robustness check, we examine the performance of the trading strategies after re-sampling the data based on factors such as size of market capitalization and level of book-to-market ratio. The results remain consistent with our main findings.

We further extend our analysis by incorporating a unique phenomenon observed in China. In particular, as explained, individual investors dominate the Chinese stock market and some empirical studies (e.g., Goetzmann and Kumar, 2005; Meulbroek, 2005; Mitton and Vorkink, 2007) show that this type of investors often hold under-diversified portfolios with a small number of stocks. ${ }^{2}$ To reflect this, we examine whether our findings remain consistent even if we incorporate no more than 60 stocks in our long-short portfolios. The results again indicate the existence of abnormal returns.

The remainder of this paper proceeds as follows. Section 2 explores the relevant literature. Section 3 explains the methodologies and the data used in this study. Section 4 discusses the empirical results and Section 5 concludes.

\section{Literature review}

\subsection{Firm characteristics and the cross-section of stock returns}

A large body of literature examining the relationship between firm characteristics and stock returns mainly focuses on the variables pertinent to the market information. Those

\footnotetext{
${ }^{1}$ We also test the existence of abnormal returns through six-factor model presented in Fama and French (2018). This model adds a momentum factor to the five-factor model. The results are consistent with those obtained by using the five-factor model.

${ }^{2}$ Mitton and Vorkink (2007) show that this phenomenon may be driven by the preference of individual investors towards increase in the likelihood of extreme positive returns.
} 
include the firm size (e.g., Banz, 1981; Reinganum, 1983), the book-to-market ratio (e.g., Lakonishok et al., 1994; Asness et al., 2013), short- and long-term historical returns (e.g., Jagadeesh and Titman, 1993; Barroso and Santa-Clara, 2015; DeBondt and Thaler, 1985), and the accounting information such as accruals, investment capitals and profitability measures (e.g., Lawrence, 2013; Sloan, 1996; Dechow et al., 2012; Allen et al., 2013; Mao and Wei, 2016; Fama and French , 2006; Novy-Marx, 2013; Kogan and Papanikolaou, 2014).

Related to the studies focusing on the Chinese stock market, recent works find that measures such as firm size, book-to-market ratio, momentum, and trading volume are useful predictors of future stock returns (see $\mathrm{Wu}$ and $\mathrm{Wu}, 2003$; Wang and Guo, 2014). These studies indicate that the characteristics of companies possess useful information to effectively predict future stock return. Nevertheless, these studies do not show whether the factors that they considered are capable of effectively explaining the risks under various circumstances. Thereby, the risks are yet identified as anomalies.

With regard to the practical use of these findings, it is not an easy task to establish a trading strategy by incorporating all of the abovementioned factors. One crucial issue is the number of stocks required to form portfolios by following these findings. For example, if an investor divides the listed companies into three groups (e.g., large, medium and small) and wishes to examine the performance of portfolios reflecting seven different characteristic measures simultaneously, such investor would need to create 2,187 portfolios. Furthermore, to conduct a comprehensive analysis on these portfolios, each of them needs to be well-diversified and thereby requires an extremely large number of companies. A recent 
literature survey conducted by Harvey et al. (2016) show that there are at least 316 financial anomalies discovered in the past. If an investor wishes to examine the effectiveness of using all these anomalies to build trading strategies, the required number of stocks to construct portfolios will become extremely large. Hence, our paper contributes towards a more workable way of profiting from the predictability of stock returns based on the use of arbitrage risk.

\subsection{Risk arbitrage and anomalies}

Turning to the focal risk measure of our study, arbitrage risk has been used in previous studies to explain anomalies (e.g., Ali et al., 2003; Lam and Wei, 2011; Chou et al., 2013). For example, Ali et al. (2003) examine the book-to-market ratio anomaly using arbitrage risk. Similarly, Lam and Wei (2011) use arbitrage risk to explain the anomaly arising from the asset growth rate factor. In addition, Chou et al. (2013), in the examination of the predictive power of the turnover effect, show that such a power elevates along with the level of arbitrage risk. There are ensuing studies including Stambaugh et al. (2015), Ye and Zhou (2013), Ren (2014) and Zhang and Liu (2014) examining the turnover and asset growth effects. They show that differences in the degree of arbitrage risk influence the effect of anomalies on the cross-section of future stock returns. These studies note that the existence of arbitrage risk enables us to forecast the cross-section of stock returns from firm characteristics.

Furthermore, by studying stocks with a higher level of arbitrage risk, Baker and Wurgler (2006) find that such risk leads to a stock mispricing and they argue that this cannot 
be corrected quickly. Related to this, Shleifer and Vishny (1997) suggest that the existence of arbitrage limitations prevents stock prices from returning to their fundamental values through rational arbitrage and this leads to a long-term mispricing.

Subsequent studies find that imperfect information and market friction hinder investors' arbitrage behaviors, preventing them from exploiting arbitrage opportunities. This is because a high level of information uncertainty costs investors more to understand the correct values of assets. Greater market friction leads to a higher fixed cost of arbitrage for investors, and rational investors' willingness to arbitrage is reduced unless the profit from the arbitrage is higher than the cost (Merton, 1987; Gerhold et al., 2014). Moreover, Chou et al. (2013) state that the existence of noise traders is part of the cost that needs to be paid by rational investors for arbitrage.

Baker and Wurgler (2013) and Baker et al. (2012) further indicate that investor sentiment has a significant impact on the cross-sectional stock returns. If a firm is new, of small size, having highly volatile prices, unprofitable, in financial distress, or experiencing extreme growth, its stock prices are prone to influences from investor sentiment, which will result in mispricing. Therefore, those firm characteristics can explain the cross-section of stock returns.

On measuring arbitrage risk, Ali et al. (2003), Chou et al. (2013), Lam and Wei (2011) and Stambaugh et al. (2015) indicate three proxies: noise trader risk represented by idiosyncratic volatility, transaction costs and information uncertainty. Our study follows these to decompose the arbitrage risk. In relation to the effect of idiosyncratic volatility, there exist 
inconclusive discussions about how the stock returns are related to such type of volatility. In particular, there are studies claiming a positive relation (e.g., Merton, 1987; Barberis and Huang, 2001; Malkiel and Xu, 2002; Ewens at al., 2013) while some others argue that they are negatively related (e.g., Ang et al., 2006; Stambaugh et al., 2015; Chen et al., 2012). Although the sign of the association is not our main focus, Stambaugh et al. (2015) claim that the combined effects of arbitrage risk and arbitrage asymmetry cause the relationship to be negative. If this argument holds in the Chinese market, we see a negative association between the estimated idiosyncratic volatility and the stock return. Following the above explained studies, we use the idiosyncratic volatility to represent the noise trader risk.

On our focal examination, the role of noise trader risk can be clarified using the stock pricing model stated in Brown and Cliff (2005) and Lin et al. (2015). The model is specified as

$$
P^{*}=w_{f} P_{f}+w_{s} P_{s}
$$

where $P^{*}$ represents the current stock price of the firm; $P_{f}$ represents the stock price estimated by the fundamental investors, which is the real price; $P_{s}$ is the noise measure represented by the stock price estimated by investor sentiment or speculators; $w_{f}$ is the proportion of rational investors who invest in the stock; and $w_{s}$ is the proportion of irrational investors who invest in the stock. Therefore, the current stock price is the weighted average of the two types of investors' stock price estimates.

Under the above framework, the existence of arbitrage risk in a particular stock affects the composition of the noise traders and the rational investors, such that a greater arbitrage risk means that the stock price is more prone to deviate from its fundamental value. 
When arbitrage risk is low, rational investors are more willing to hold the stock, and thus the price is closer to the "true" value. On the other hand, when arbitrage risk is high, rational investors will be less inclined to invest in such a stock, thereby causing the price to sustain a long-term deviation from its fundamental value. In such a case, due to the lack of rational investor participation, the arbitrage risk may have a strong influence over the price, and thereby, the predictive power of such a risk has on the future stock returns strengthens.

Considering the unique characteristics of the Chinese stock market where individual investors dominate and where short-selling was not allowed until very recently, the proportion of informed rational traders comprising mainly of institutional investors is relatively low. Following Equation (1), the proportion of noise traders, the counterparty of rational traders, would affect the susceptibility of the market to the presence of arbitrage risk. More specifically, the influence of arbitrage risk on the market becomes larger when the proportion of irrational investors increases. This indicates that arbitrage risk will have a higher predictive power over the stock returns in the Chinese market.

Moving to the transaction cost, investors are incapable of understanding the true value of a stock when the stock price of such a company is highly volatile. This equates to the cost of arbitrage activities. Ultimately, when the transaction cost is high, an exploitable arbitrage profit will be lower than the transaction cost and causes investors to arbitrage less. In other words, the transaction costs may impose barrier to arbitrage (Mashruwala et al., 2006). A study of Mashruwala et al. (2006) using proxies including the stock price and the trading volume show that the accrual anomaly is observed in companies with low-price and 
low-volume. Relating to the intensiveness of trading, Chou et al. (2013) find that companies with lower turnover have higher future returns. On the estimation, as it is not possible to directly observe the overall transaction costs the majority of investors pay, many proxies including the intensity of trading are used in the past studies (in many cases, simultaneously in one model).

In our examination, we employ the following five proxies to represent the transaction costs. Those are (1) the closing price (see Ali et al., 2003; Lam and Wei, 2011; Mashruwala et al., 2006), (2) the illiquidity indicator of Amihud (2002), (3) the share turnover (see Ali et al., 2003, Lam and Wei, 2011; Mashruwala et al., 2006), (4) the institutional investor shareholding (see Ali et al., 2003), and (5) the days with no trading executed. Lesmond et al. (2004) and Ali et al. (2003) argue that a security with higher transaction costs have more days with zero returns than that with lower transaction costs. For this reason, they employ the number of days with zero returns as a proxy for the transaction costs. Extending from this, we use a more direct measure of the days with no transaction being executed.

Lastly, information uncertainty is measured against the uncertainty of the fundamental value of a firm. When investors do not understand the fundamental value of the firm, they are incapable of discerning the existence of mispricing between the stock price and the firm value. Therefore, a higher level of information uncertainty reduces professional investors' arbitrage behaviors. Relating with anomalies, Wang and Yu (2013) find that the information uncertainty is closely related to the emergence of anomalies. Despite its 
importance, like the transaction costs, it is not directly observable, and therefore identifying the proxies is necessary to conduct an empirical study. Ali et al. (2003), Lam and Wei (2011) and Chou et al. (2013) use the number of institutional owners as a proxy. They claim that such ownership measures the investor shrewdness or sophistication. The investor sophistication should be related to the extensiveness of analysis conducted on the relevant company. Hence, the larger the number of institutional owners, the higher the certainty of the information delivered to the market. In this study, in addition to the number of institutional owners, following Lam and Wei (2011) we use two other measures: the analyst coverage and the cash flow variability.

\section{Data and Methodologies}

\subsection{Data}

The main objective of this study is to disentangle the dynamic role of arbitrage risk in forecasting the stock returns and constructing a profitable portfolio in China. We examine these by testing the predictability of stock returns using the proxies of arbitrage risk and the presence of abnormal returns in constructed portfolios. In the examination, as explained above, we decompose arbitrage risk into three categories: noise trader risk, transaction costs and information uncertainty. Since these categorized components are not directly observable, we employ the following proxies to measure them (refer to the previous section for the details include the rationales behind the selection of the following measures). The noise trader risk is represented by idiosyncratic volatility. Transaction costs are measured using five proxies: 
closing price, illiquidity indicator, share turnover, institutional investor shareholding and days without transaction. Lastly, information uncertainty is measured by cash flow variability and the number of (1) analyst coverage and (2) institutional owners. The estimation methods of these variables are explained later in this subsection.

Our data are obtained from the China Stock Market \& Accounting Research Database so called GTA database. This database provides financial information of individual companies listed in the Chinese stock markets. This includes the stock price, the market capitalization, and the turnover value of listed firms in a daily frequency. It also offers the financial statement information of companies, the market return and the risk-free interest rate. We obtain the net value of the annual shareholders' equity, total assets, and operating cash flow of firms from the financial statement dataset. For analysts' earnings forecast report, we use the security analyst dataset, and for the shareholding proportion of institutional investors, we use the equity information in the shareholder information dataset. Focusing on the A-shares traded in China, our overall sample covers the period May 2003 - December $2016^{3}$ and consists of 8,352,366 daily observations from 1,995 companies. The collected data are then converted to monthly observations. To avoid sample selection bias, we exclude the special treatment shares ${ }^{4}$ during the sample period. Our final sample for the cash flow uncertainty measure comprises of 114,826 firm-month observations.

\footnotetext{
3 The sample period is determined by the availability of data, especially the annual report data which we take the five-year average for some variables including the cash flow variability.

${ }^{4}$ These are stocks with abnormal financial conditions such as those that reported two consecutive years of audited net losses. From April 22, 1998, the stock exchanges added letters "ST" to the security code of a company to alert investors about the inclusion of the company in a special treatment list. For further details, see Zhou (2013).
} 
The idiosyncratic volatility (IVOL) is estimated by taking the standard deviation of the residuals obtained from the Fama and French (1993) three-factor pricing model. At month $t$, the residuals of the three-factor model are obtained using the stock returns of the past 36 months (from $t$-36 to $t-1$ ). We require a company to have all the 36 monthly returns in these 3 years and for this reason, we drop companies with missing returns.

Next, the transaction cost measures are estimated as follows. For the closing price, we use the previous month price (Close). The illiquidity indicator (ILLIQ) proposed by Amihud (2002) is estimated by taking the absolute value of the relevant day's stock return divided by its turnover value. In the analysis, we convert the estimated illiquidity measures into monthly frequency. To be more specific, for month $t$, we take the average of the daily illiquidity measure between the months $t-12$ and $t-1$. The stock turnover itself (Turnover) for month $t$, is estimated by taking the average of the monthly turnover rate between months $t-12$ and $t-1$. The institutional investor holdings (InstHld) are measured by the percentage of the shares held by such type of investors. As this information is disclosed every 6 months, to avoid a look-ahead bias, for January to June of year $z$, we use the values found in the report published in December of year $z-1$, and for July to December of year $z$, we use the values found in the report published in June of year $z .^{5}$ Then the number of zero-trading days (ZeroTrade) for month $t$ is calculated by counting the number of days with no trading occurred for stock $i$ over the months between $t-12$ and $t-1$.

Information uncertainty is measured using analysts' coverage $(C O V)$, cash flow

\footnotetext{
5 In the case of missing observation, we assign a value of zero.
} 
volatility $(C V O L)$, and the number of institutional owners (InstNum). The COV of month $t$ is calculated by counting the number of earnings forecast reports released by equity analysts for the company during the period between months $t-12$ and $t-1$. The value of zero is assigned if there is no report being released. The CVOL is the five-year standard deviation of the ratio estimated by dividing the operating cash flow by the total assets of companies. In estimating the standard deviation of the cash flow/total asset ratio, to ensure that the financial information has been fully disclosed, we combine the data obtained at the end of year $z-1$ with the monthly data between May of year $z$ and April of year $z+1$. Since the earliest annual report data obtainable for our study are from 1998 and we use five-year average figures for cash flow and total assets, the first calculable cash flow uncertainty is the value at the end of 2002. For this reason, our analysis covers the period starting from 2003. In addition, for this measure, we treat missing values in a similar manner in relation to the percentage of institutional holding. That is, we assign the value of zero if data is missing. In addition to this, we winsorize the variables at the $1 \%$ and $99 \%$ levels to minimize the influence of extreme values.

Table 2 shows the descriptive statistics of the variables used in this study. In the table, we first compute the cross-sectional averages of all the variables for each month. Then using these average figures, we calculate the means, standard deviations, minimums, first quartiles, medians, third quartiles, and maximums during the sample period. The results in Table 2 indicate that within the sample period, the average monthly return for China's A stock is $1.9 \%$, with the most underperforming month being $-28.7 \%$ and the top-performing month being $36.1 \%$. In addition, more than half of the sample period yield a return of over $2.0 \%$. The mean of IVOL is $42.8 \%$ and this indicates that a relatively high noise trader risk exists in 
China's A share market.

Turing to the market liquidity, ILLIQ and Turnover variables indicate that the Chinese stock market is highly liquid. The liquidity level of Chinese market is also evident from the equity market turnover ratio estimated by the World Federation of Exchanges. Since 2013, the Chinese stock market has had a higher liquidity level than the U.S. stock market. ${ }^{6}$ Related to this, the mean of the percentage of institutional investor holding is $4.1 \%$. This shows that such liquidity mainly comes from the activities of individual investors. Although the market is relatively liquid, on average, there are 5.8 days without any trading activities over 12 months.

Next, the average number of analyst forecast reports published over the past 12 months is 26.4 . Since the minimum value of this variable is 0.61 , there is a large variability in the frequency of analysts changing their forecasts. The average of the cash flow/total asset ratio standard deviation is $4.4 \%$, with minimum and maximum values of $3.6 \%$ and $5.0 \%$, respectively. This indicates that the cash flow standard deviation has low volatility. Finally, the average number of institutional owners is 19.9 , while the minimum and the maximum values are 2.7 and 54.1, respectively. This implies that the institutional investors frequently change their holding positions.

[Insert Table 2 here]

\subsection{Testing Methodologies}

To test the predictive power of the above-mentioned measures, we derive the

\footnotetext{
6 As of 2017, the value of equity market turnover ratio in China is 1.6 times higher than the U.S. stock market, as per data from the World Federation of Stock Exchanges provided by the World Bank (https://data.worldbank.org/indicator/CM.MKT.TRNR).
} 
following models. These models are also used to construct portfolios (i.e., Equation (2) is for the portfolio strategy 1, Equation (3) is for the strategy 2, Equation (4) is for the strategy 3 and Equation (5) is for the strategy 4).

$$
\begin{gathered}
R_{i, t}=a_{t}+b_{t} \text { IVOL }_{i, t-1}+\epsilon_{i, t} \\
R_{i, t}= \\
a_{t}+b_{t} \text { Close }_{i, t-1}+c_{t} \text { ILLIQ }_{i, t-1}+d_{t} \text { Turnover }_{i, t-1}+ \\
R_{i, t}=a_{t}+b_{t} \text { IVOL }_{i, t-1}+c_{t} \text { Close }_{i, t-1}+d_{t} \text { ILLIQ }_{i, t-1}+e_{t} \text { Turnover }_{i, t-1}+ \\
f_{t} \text { InstHld }_{i, t-1}+g_{t} \text { ZeroTrade }_{i, t-1}+\epsilon_{i, t} \\
R_{i, t}=a_{t}+b_{t} \text { IVOL }_{i, t-1}+c_{t} \text { Close }_{i, t-1}+d_{t} \text { ILLIQ }_{i, t-1}+e_{t} \text { Turnover }_{i, t-1}+ \\
f_{t} \text { InstHId }_{i, t-1}+g_{t} \text { ZeroTrade }_{i, t-1}+h_{t} \operatorname{Cov}_{i, t-1}+i_{t} \text { CVOL }_{i, t-1}+ \\
j_{t} \text { InstNum }_{i, t-1}+\epsilon_{i, t}
\end{gathered}
$$

where $R_{i}$ is the return of stock $i$.

In the actual test, we follow the method of Lewellen (2015) using the Fama and MacBeth (1973) cross-sectional regression. To be more specific, for each month we run a cross-sectional regression using the above equations to obtain betas for each variable and the value of $R$-squared. Then, we compute the average value of coefficients over the specified period. We first test the significance of theses coefficients and then in the latter part of the analysis, we use these estimates to forecast expected returns.

To test the effectiveness of the out-of-sample expected returns, we run the following 
regression used by Lewellen (2015),

$$
R_{i, t}=a_{t}+\beta_{t} \widehat{R_{l, t}}+\epsilon_{i, t}
$$

where $\widehat{R_{l, t}}$ is the forecast returns obtained from Equations (2) - (5) using the steps explained above. In this analysis, we also use the Fama-MacBeth regression approach where we first run cross-sectional regression each month and then take the average of betas over the sample period.

Next, we adopt the approach of Jagadeesh and Titman (1993) to establish a total of 16 hypothetical investment portfolios: 4 formation periods $\times 4$ strategies. Hereinafter, the strategies used in constructing portfolios equate to the models explained in Equations (2) (5); for simplicity, we now use the term "strategy" to explain the model used in the hypothetical portfolio estimation.

The portfolios are constructed as follows. For each month, the sample companies are sorted into ten groups based on the level of the forecast returns estimated using the method explained above. Then, we form zero-cost value-weighted portfolios by buying the companies in the top 10 percentile and selling the ones in the bottom 10 percentile. In other words, we buy the expected winners and sell the expected losers. In addition, in forming portfolios we apply four different formation periods: 1, 3, 6 and 12 months.

The performance of our hypothetical portfolios is examined by testing the existence of abnormal returns/anomalies. Here, we employ the three- and five-factor models formulated by Fama and French $(1993,2015)$. The actual models are respectively 


$$
\begin{aligned}
& r_{t}=a+\beta_{M} R M R F_{t}+\beta_{s m b} S M B_{t}+\beta_{h m l} H M L_{t}+\epsilon_{t}, \\
& \begin{array}{l}
r_{t}=a+\beta_{M} R M R F_{t}+\beta_{s m b} S M B_{t}+\beta_{h m l} H M L_{t}+\beta_{r m w} R M W_{t} \\
\quad+\epsilon_{t},
\end{array}
\end{aligned}
$$

where $r_{t}$ is the return obtained from zero-cost portfolio, $\alpha$ is the abnormal return obtained from the portfolio, $R M R F$ is the market excess return, $S M B$ is the difference in the performance of the small stock portfolio and the big stock portfolio, $H M L$ is the difference in the performance of the value portfolio and the growth portfolio, $R M W$ is the difference in the performance of the robust operating profitable portfolio and the weak operating profitable portfolio, and CMA is the difference in the performance of the conservative investment portfolio and the aggressive investment portfolio. We estimate those variables based on the methods presented in Fama and French $(1993,2015)$.

\section{Empirical Results}

\subsection{Arbitrage risk on stock returns}

We first examine how our variables are associated with each other. Table 3 shows the correlation coefficients between the variables. Following Ali et al. (2003) and Chou et al. (2013), we first estimate the cross-sectional correlations among the variables in a monthly frequency, and then we compute the average values over our sample period. It appears that most of the variables are correlated. As we initially expected, the idiosyncratic volatility and the stock return are negatively related. This supports the view of Stambaugh et al. (2015) arguing that the two variables are related through the combination of the arbitrage risk and arbitrage asymmetry effects, and for this reason, there exists a negative association.

Furthermore, interestingly, the number of analyst forecast reports and the number of institutional owners are highly related. While this is not our main focal point, there are two 
possible explanations for this relationship. The first explanation is that as institutional owners are the primary customers of equity analysts, the number of such type of owners may affect how extensively the equity analysts look after the company. The second explanation is that as the information uncertainty reduces when more reports on a company are published by analysts, institutional investors become more inclined to hold the shares of such a company. As institutional investors and equity analysts are important players in the equity market, it is worthy to further investigate this relationship in a future study. To take the non-normally distributed nature of our variables, we also compute the Spearman's rank correlation among our variables. The results are consistent with the Pearson's correlation figures. For the sake of brevity, the results are not reported here.

\section{[Insert Table 3 here]}

Next, before testing the aforementioned models (Equations $(2)-(5)$ ), we examine the in-sample forecasting power of the focal variables. For this, we use the Fama-MacBeth cross-sectional regression approach. To be more specific, we first run the cross-sectional regression for each month and then we compute the time-series mean of the coefficients and the adjusted $R$-squared statistics. The results are reported in Table 4. The results in Column (1) are for the noise trader risk, Column (2) for the transaction costs, Column (3) for the information uncertainty, Column (4) for the noise trader risk and the transaction costs, Column (5) for the noise trader risk and the information uncertainty, and Column (6) for the impacts of all three arbitrage risk measures.

The results in Table 4 show that the noise trader risk has a negative impact on the stock return in the subsequent period, which suggests that higher arbitrage risk leads to lower 
stock return. This is consistent with the initial expectation drawn from Stambaugh et al. (2015), a negative relationship between the two variables. A similar relationship is observed between the information uncertainty measures and the returns in the subsequent period. The coefficient of the analyst report variable is found to be significantly positive at the $10 \%$ level. In addition, the institutional ownership obtains a significantly positive coefficient when all the variables are incorporated in the model. In contrast, the variability of cash flow/total asset ratio has a positive coefficient, indicating that higher arbitrage risk leads to higher stock return. Further mixed results are obtained for the transaction cost measures. Particularly, while the turnover rate has a negative impact on the return throughout the tests, the sign of institutional holding rate changes depending on other controlling variables used. Together with the result of the illiquidity measure which shows a positive and significant coefficient on the full model, the result of the turnover measure is consistent with the idea of illiquidity premium discussed by studies such as Amihud (2002). Thus, these results are in line with our initial expectations explained in the earlier section.

In relation to the main focus of this study, the value of the adjusted $R$-squared suggests that arbitrage risk measures collectively can explain $29 \%$ of the variation of future stock returns. In contrast, a full-sample test of Lewellen (2015) which focuses on the U.S. market and using conventional measures of firm characteristics such as the book-to-market ratio, yields an adjusted $R$-squared value of less than $10 \%$. Furthermore, in our study, the value substantially improves when all the measures are included in the model. This indicates 
that arbitrage risk is capable of predicting the subsequent stock returns. ${ }^{7}$

[Insert Table 4 here]

Nevertheless, it is still unclear whether investors can exploit such predictive power of the arbitrage risk and establish profitable investment strategies. In other words, the predictive ability may merely be an in-sample phenomenon. To address this, we conduct an out-of-sample tests by following Lewellen (2015). Here, we use Equations (2) - (5) to run a Fama-MacBeth cross-sectional regression and estimate out-of-sample expected returns. To be more specific, in the first step, we run the cross-sectional regression to obtain the coefficient of each variable for each month. Then, in the second step, we compute the average of the coefficients (slopes) for those variables over the past 12, 24 and 36 months. Finally, we estimate the expected return, $\left(\widehat{R_{t}}\right)$, of company $i$ for the following month by computing the product of the average slopes and the arbitrage risk measures of the contemporary month. The effectiveness of the predicted returns is tested using Equation (6).

The out-of-sample test results are displayed in Table 5. If our models provide an unbiased forecast of returns, the coefficient obtained from the regression analysis should be one. The results show that there exists a positive relationship between the forecast and the actual returns. Panel A of the table uses 12-month rolling beta estimates in the second step of the Fama-MacBeth cross-sectional regression to forecast returns of individual stocks. The coefficients vary from 0.16 to 1.33 . The highest coefficient is obtained for the model

\footnotetext{
${ }^{7}$ We conduct the same analysis on Table 4 by including the five factors of Fama and French (2015) and the momentum factor to check the robustness of our results. As the results generally remain the same, we do not report them here.
} 
consisting only of the noise trader risk; however, the significance level is marginal at the $10 \%$ level. For other results, while the full-model (Equation (5)) obtains a highly significant result, the other two models obtain insignificant results even at the $10 \%$ level.

Panels B and C provide the results using 24- and 36- month rolling beta estimates, respectively, in the second step of the Fama-MacBeth cross-sectional regression. Observing from the significance of the coefficient, the expected returns generally are better representations of the actual returns when longer than 12-month information is incorporated. Turning to the explanatory power, it appears that incorporating 24-month information generally forecasts the returns of Chinese stocks more effectively.

Overall, Table 5 reveals that the four models do a good job in capturing variation in expected returns. However, the question remains as to whether the models help investors to establish an effective trading strategy.

[Insert Table 5 here]

\subsection{Tests on trading strategies}

We now test the effectiveness of the arbitrage risk in constructing investment portfolios. The portfolios are constructed by the method explained in the previous section. In theory, if the arbitrage risk effect is illusional, the well-established asset pricing models, as shown in Equations (7) and (8), should capture this effect. In such a case, the intercept obtained by regressing the returns of our portfolios using those models should be no different from zero. We also construct a momentum portfolio following the investment strategy of 
Jagadeesh and Titman (1993) and compare its performance against the performance of our portfolios.

Table 6 provides the results of our examination using the full-sample period. For each panel, we use different formation periods (additional results are also presented in Appendix). Based on the results shown in Table 5, we use 24-month average betas in the second step of the Fama-MacBeth cross-sectional regression to forecast stock returns. Broadly speaking, our analysis indicates that our portfolios indeed obtain abnormal returns and therefore the arbitrage risk measures capture valuable information unexplained in the literature. Majority of the intercepts are significantly different from zero at the 5\% level for both three- and five-factor models. ${ }^{8}$ By contrast, for the conventional momentum strategy, while the intercept shows a significant result in some cases, the signs of those are negative.

When it comes to the magnitude of the anomalies, most of the significant monthly abnormal returns are around or more than $1.0 \%$. Within the strategies, a superior performance is achieved by Strategy 3 with the noise trader risk and the transaction cost measure. This is broadly consistent throughout the formation and holding periods considered in our analysis. Strategies 1 and 2 are the nested model of Strategy 3 as each of these comprises of the noise trader risk and the transaction cost measure, individually. An examination of these two strategies show that the contribution of each factor on the performance of Strategy 3 varies depending on the formation and the holding periods. Therefore, the performance of a portfolio can be stabilized by incorporating both factors.

\footnotetext{
${ }^{8}$ The results remain similar even when the six-factor model in Fama and French (2018) is used.
} 
All in all, our examination provides evidence that arbitrage risk contains valuable information that is not well-explained by the conventional asset pricing model. Such information can be used to form an effective portfolio. Nevertheless, the results may be contaminated by the sampling bias such as the periods used in the second step of the Fama-MacBeth cross-sectional regression and other anomaly effects. For this reason, we extend our examination in the next sub-section to address this issue.

\section{[Insert Table 6 here]}

\subsection{Robustness of the results}

We reconstruct portfolios by (1) using the 12 and 36 months average coefficients to forecast stock returns, (2) excluding January, and (3) grouping the companies based on their market capitalization, book-to-market ratio and the liquidity level. Then we examine the existence of abnormal returns obtained from the constructed portfolios. Here, for the sake of brevity, we use a 3-month formation period to form portfolios and the Fama-French five-factor model in the examination. ${ }^{9}$

The results are presented in Table 7 . To keep the presentation concise, we only report the values of the intercept and the $t$-statistics. It appears that the rolling periods used in the second step of the Fama-MacBeth cross-sectional regression has a marginal impact on our results. At a basic level, the results convey the same message as our earlier tests; the intercept generally is statistically significant throughout different holding periods (represented as " $k$ "

\footnotetext{
${ }^{9}$ We also employ the six-factor model in Fama and French (2018) to further check the robustness of our results. We confirm the stability of our results.
} 
in the table). It is worth noting that the contribution of the noise trader becomes slightly weaker this time.

Next, we exclude the performance of January in the examination to account for the January effect discussed in the literature (e.g., Reinganum, 1983; Thaler, 1987). ${ }^{10}$ The overall results remain consistent and therefore our factors are less influenced by the January effect. We now test whether abnormal returns can be obtained even when the portfolios are formed within a group of small, medium and large size companies. For this, we firstly sort the companies into three groups based on their market capitalization in every June. The first group comprises of the companies in the top 30 percentile, the second group consists of the companies within the following 40 percentile, and finally the third comprises of the bottom 30 percentile. Within each group, we further sort the companies into ten groups based on the estimated forecast returns. Then, we construct a zero-cost portfolio like we did in the previous section, taking long positions in the stocks expected to be the winners and shorting the ones expected to be the worst performers. Our analysis shows that the considered strategies yield abnormal returns among small- and medium-size companies. The results further suggest a marginal contribution of the noise trader risk in obtaining such returns. When it comes to the larger stocks, it appears that our strategies have a limited predictive power. This is consistent with Baker and Wurgler (2013), who argue that large firms are not strongly affected by investor sentiment.

\footnotetext{
${ }^{10}$ While there are some studies like Kling and Gao (2005) and Zhang and Li (2006) showing that the January effect is somewhat weak in China due to the absence of tax benefits, we take such effect into account to further strengthen our basic results.
} 
Apart from the size effect, we also take the value factor into consideration in re-sampling the companies. To be more specific, same as in the case of the size factor, we divide companies into three groups based on their book-to-market ratio and then form zero-cost portfolios. The resampling is done in June based on the book-to-market ratio estimated from the financial information at the end of December in the previous year. The results in general remain consistent with the previous analyses throughout the three resampled groups. Lastly, we resample the companies based on their liquidity level represented by the average turnover ratio over the previous year. The resampling is again done in every June and likewise, we form three groups and construct zero-cost portfolios. No substantial impact on obtaining positive abnormal returns is observed even when we use relatively illiquid companies to form a portfolio.

All in all, our reexaminations further confirm the arbitrage risk effect in obtaining abnormal returns. To be more specific, the noise trader risk and the transaction costs effect lead to abnormal returns. However, the level of partial contributions that each of these risk categories has on the performance appears to vary with the sample used. For this reason, it is recommended to combine both risk categories to form an investment strategy in China. Further, on the performance of the conventional momentum strategy, it appears that such a strategy does not do a good job in obtaining abnormal returns.

[Insert Table 7 here]

\subsection{Practical application of the strategies}

Now we examine a practical application of our strategies. Here, we further resample 
our data and reconstruct portfolios by adopting the characteristics of the Chinese stock market. To be more specific, we restrict our portfolio construction period to post-2010, when short-selling was fully adopted in the country. Furthermore, we limit the loser companies to those allowed by the regulator to short-sell. Lastly, to account for the unique investor composition in China, our portfolios incorporate a small number of companies. This is particularly important as the Chinese stock markets are dominated by individual investors and it is not easy for them to simultaneously trade a large number of companies. More specifically, since there are more than 2,000 stocks listed in the Shanghai and Shenzhen stock exchanges, collectively, our full-sample portfolios comprise of at most 400 companies (buying 200 and selling 200 companies). Even for the sub-sampled portfolios, we require a large number of companies.

Our argument is supported by the past empirical studies which examine the stock holding of individual investors. In particular, while modern portfolio theory postulates that investors should hold a well-diversified portfolio, individual investors often hold an under-diversified portfolio (Goetzmann and Kumar, 2005; Meulbroek, 2005; Mitton and Vorkink, 2007).

To account for this, we construct portfolios by buying and selling the sum of 10 companies, 20 companies, 30 companies, 40 companies, 50 companies and 60 companies, respectively. We are buying and selling an equal number of companies. The results presented in Table 8 show that Strategies 2 and 3 result in statistically significantly positive abnormal returns, regardless of the holding period used. Thus, the results are consistent with those 
obtained in the previous sections and support the effectiveness of using arbitrage risk measures to construct equity investment portfolios in China. ${ }^{11}$ In addition to these robustness tests, to take a recent development of asset pricing models, we reconducted the tests presented in Tables $6-8$ using the six-factor model presented in Fama and French (2018), which is the Fama-French five-factor model plus the momentum effect. The results remain robust (for the sake of brevity, the results are not reported).

\section{[Insert Table 8 here]}

\section{Conclusions}

Over the last few decades, the stock markets in China have grown rapidly and the Shanghai and Shenzhen stock exchanges are now some of the largest in the world in terms of the overall market capitalizations of listed companies. However, the Chinese stock markets still possess various unique characteristics. We examine the cross-sectional predictive power of the arbitrage risk on the stock returns in this unique market. Using the Fama-MacBeth cross-sectional regression approach, we find that the arbitrage risk, represented by noise trader risk, transaction costs and information uncertainty, possesses valuable information to explain future cross-sectional stock returns. These results are confirmed with the out-of-sample tests. To further examine the information inherent in the arbitrage risk measures, we establish four trading strategies and form hypothetical portfolios. As a comparison, we construct a momentum portfolio and test the presence of abnormal returns

\footnotetext{
11 We acknowledge that considering transactions costs (e.g., bid-ask spread) to construct portfolios may reduce the performance of examined trading strategies. However, such cost factor does not alter the superior performance of the strategies against the momentum investment strategy.
} 
based on the multi-factor models of Fama-French. The examinations indicate the existence of the abnormal returns in our portfolios as well as the superiority of these portfolios in obtaining such return against the momentum approach.

To check the robustness of our results, we resample the observations through different approaches such as sub-grouping the companies based on their market capitalization, the level of their book-to-market ratio and their liquidity level. Our examinations again confirm the presence of the abnormal returns in the portfolios. Lastly, to account for the unique nature of the Chinese stock market, we re-construct our portfolios by limiting the number of companies to build a portfolio and by applying the strategies to the sample observations after 2010. This is an important procedure as the Chinese stock market is still dominated by individual investors. The analysis again indicates the presence of abnormal returns.

Our study differs from previous studies in a number of aspects. First, we consider the predictive power of stock returns to construct trading strategies and examine a practical application of such strategies in forming profitable portfolios in the Chinese stock market. Secondly, although we follow the approach of Lewellen (2015) in the analyses and construction of portfolios, we focus on the variables related to arbitrage risk (i.e., factors influencing investors' emotion) while Lewellen focuses on anomaly-related variables. In this regard, our study contributes to generalizing Lewellen's approach. Thirdly, we extend our portfolio construction by adopting the unique nature of the Chinese stock market. To be more specific, we show that our strategies are implementable by individual investors who dominate 
the Chinese market. Our analyses provide further evidence of applying the out-of-sample Fama-MacBeth cross-sectional regression to construct effective investment portfolios. Future studies can examine these strategies in other stock markets. 


\section{References}

Ali, A, Hwang, LS, and Trombley, M. 2003. Arbitrage risk and the book-to-market anomaly. Journal of Financial Economics, 69(2): 355-373.

Allen, E, Larson, C, and Sloan, RG. 2013. Accrual reversals, earnings and stock returns. Journal of Accounting and Economics, 56(1): 113-129.

Amihud, Y, 2002. Illiquidity and stock returns: Cross-section and time-series effects. Journal of Financial Markets, 5(1): 31-56.

Ang, A, Hodrick, RJ, Xing, Y, Zhang, X. 2006. The Cross-Section of Volatility and Expected Returns. Journal of Finance, 61(1): 259-299.

Asness, CS, Moskowitz, TJ, and Pedersen, LH. 2013. Value and momentum everywhere. Journal of Finance, 68(3): 929-985.

Baker, M, Wurgler, J. 2006. Investor Sentiment and the Cross-Section of Stock Returns. Journal of Finance, 61(4): 1645-1680.

Baker, M, and Wurgler, J. 2013. Behavioral corporate finance: An updated survey. Handbook of the Economics of Finance, Elsevier, Volume 2, Part A, Chapter 5: 357-424.

Baker, M, Wurgler, J, and Yuan, Y. 2012. Global, local, and contagious investor sentiment. Journal of Financial Economics, 104(2):272-287.

Banz, R. 1981.The relationship between return and market value of common stock. Journal of Financial Economics, 9(1): 3-18.

Barberis, N, and Huang, M. 2001. Mental Accounting, Loss Aversion, and Individual Stock Returns. Journal of Finance, 56(4): 1247-1292.

Barroso, P, and Santa-Clara, P. 2015. Momentum has its moments. Journal of Financial Economics, 116(1): 111-120.

Brown, G, and Cliff, M. 2005. Investor sentiment and asset valuation. Journal of Business, 78(2): 405-440.

Chen, L, Jiang, G, Xu, D, Yao, T. 2012. Dissecting the Idiosyncratic Volatility Anomaly. Washington State University, Gonzaga University, and University of Iowa Working Paper.

Chou, P, Huang, T, and Yang, H. 2013. Arbitrage risk and the turnover anomaly. Journal of Banking and Finance, 37(11): 4172-4182.

DeBondt, W, and Thaler, R. 1985. Does the stock market overreact? Journal of Finance, 40(3): 793-805. 
Dechow, PM, Hutton, AP, Kim, JH, and Sloan, RG. 2012. Detecting earnings management: A new approach. Journal of Accounting Research, 50(2): 275-334.

Ewens, M, Jones, CM, Rhodes-Kropf, M. 2013. The Price of Diversifiable Risk in Venture Capital and Private Equity. Review of Financial Studies, 26(8): 1854-1889.

Fama, EF, French, KR. 1993. Common Risk Factors in the Returns on Stocks and Bonds. Journal of Financial Economics, 33(1): 3-56.

Fama, EF, and French, KR. 2006. Profitability, investment, and average returns. Journal of Financial Economics, 82(3): 491-518.

Fama, EF, and French, KR. 2015. A five-factor asset pricing model. Journal of Financial Economics, 116(1):1-22.

Fama, EF, and French, KR. 2018. Choosing Factors. Journal of Financial Economics, 128(2): 234-252.

Fama, EF, and MacBeth, JD. 1973. Risk, return, and equilibrium: Empirical tests. Journal of Political Economy, 81(3): 607-636.

Gerhold, S, Guasoni, P, Muhle-Karbe, J, and Schachermayer, W. 2014. Transaction costs, trading volume, and the liquidity premium. Finance and Stochastics, 18(1): 1-37.

Goetzmann, W, and Kumar, A. 2005. Why do individual investors hold under-diversified portfolios? Yale School of Management Working Paper.

Harvey, CR, Liu, Y, and Zhu, H. 2016.... and the cross-section of expected returns. Review of Financial Studies, 29(1): 5-68.

Jagadeesh, N, and Titman, S. 1993. Returns to buying winners and selling losers: Implication for market efficiency. Journal of Finance, 48(1): 65-91.

Kling, G, and Gao, L. 2005. Calendar Effects in Chinese Stock Market. Annals of Economics and Finance, 6(1): 75-88.

Kogan, L, and Papanikolaou, D. 2014. Growth opportunities, technology shocks and asset prices. Journal of Finance, 69(2): 675-718.

Lakonishok, J, Shleifer, A, and Vishny, R. 1994. Contrarian investment, extrapolation, and risk. Journal of Finance, 49(5): 1541-1578.

Lam, FYEC, and Wei, KCJ. 2011. Limits-to-Arbitrage, Investment Frictions, and the Asset Growth Anomaly. Journal of Financial Economics, 102(1): 127-149.

Lawrence, A. 2013. Individual investors and financial disclosure. Journal of Accounting and Economics, 56: 130-147.

Lesmond, DA, Schill, MJ, Zhou, C. 2004. The Illusory Nature of Momentum Profits. Journal of Financial Economics, 71(2): 349-380. 
Lewellen, J. 2015. The Cross-section of expected stock returns. Critical Finance Review, 4(1): $1-44$.

Lin, YE, Chih, $\mathrm{HH}$, and $\mathrm{Hu}, \mathrm{CH}, 2015$. The impact of manger's sentiment on stock price: evidence from Taiwan. The Journal of Quantitative Economics, 6(1): 91-106.

Malkiel, BG, and Xu, Y. 2002. Idiosyncratic Risk and Security Returns. University of Texas at Dallas Working Paper.

Mao, MQ, and Wei, KC. 2016. Cash-flow news and the investment effect in the cross section of stock returns. Management Science, 62(9): 2504-2519.

Mashruwala, C, Rajgopal, S, Shevlin, T. 2006. Why Is the Accrual Anomaly Not Arbitraged Away? The Role of Idiosyncratic Risk and Transaction Costs. Journal of Accounting and Economics, 42(1): 3-33.

Meulbroek, L. 2005. Company stock in pension plans: How costly is it? Journal of Law and Economics, 48: 443-474.

Merton, RC. 1987. A simple model of capital market equilibrium with incomplete information. Journal of Finance, 42(3): 483-511.

Mitton, T, and Vorkink, K. 2007. Equilibrium under diversification and the preference for skewness. Review of Financial Studies, 20(4): 1255-1288.

Novy-Marx, R. 2013. The other side of value: Good growth and the gross profitability premium. Journal of Financial Economics, 108(1): 1-28.

Reinganum, MR. 1983. The anomalous stock market behavior of small firms in January: Empirical tests for tax-loss selling effects. Journal of Financial Economics, 12(1):89-104.

Ren, A. 2014. The impact of the limits of arbitrage on asset growth and stock price. Statistics \& Decision, 2014(1):155-158. [in Chinese]

Sloan, RG. 1996. Do stock prices fully reflect information in accruals and cash flows about future earnings? Accounting Review, 71(3): 289-315.

Shleifer, A, and Vishny, R. 1997. The limits of arbitrage. Journal of Finance, 52(1): 35-55.

Stambaugh, R, Yu, J, and Yuan, Y. 2015. Arbitrage asymmetry and the idiosyncratic volatility puzzle. Journal of Finance, 104(5): 1903-1948.

Thaler, RH. 1987. Anomalies: The January Effect. Journal of Economic Perspectives, 1(1): 197-201.

Wang, T, and Guo, P. 2014. Empirical evidence on the momentum strategy, value strategy and earnings forecast. Statistics \& Decision, 20:156-160. [in Chinese]

Wang, H, and Yu, J., 2013. Dissecting the Profitability Premium. Working Paper. University of Minnesota. 
$\mathrm{Wu}, \mathrm{S}$, and $\mathrm{Wu}, \mathrm{C}$. 2003. Price momentum and earnings momentum: Empirical evidence from Chinese stock market. Economic Science, 4: 41-50. [in Chinese]

Ye, J, Zhou, M. 2013. Does limits-to-arbitrage explain asset growth anomalies in A-Share market. Nakai Business Review, 16(1):41-48. [in Chinese]

Zhang, B, and Li, X. 2006. Do Calendar Effects Still Exist in the Chinese Stock Markets? Journal of Chinese Economic and Business Studies, 4(2): 151-163.

Zhang, L, Liu, W. 2014, Asset growth effect in China's stock market-based on the perspective of limits-to-arbitrage. Systems Engineering, 32(10):9-16. [in Chinese]

Zhou, L. 2013. Predicting the Removal of Special Treatment or Delisting Risk Warning for Listed Company in China with Adaboost. Procedia Computer Science, 17: 633-640. 
Table 1: The comparison of market characteristics of China and the US

\begin{tabular}{|l|c|c|}
\hline & China & US \\
\hline Number of firms & 920.87 & 4036.28 \\
\hline Return (\%) & 1.85 & 1.10 \\
\hline Market value & 5.85 & 13.04 \\
\hline Book-to-market ratio & 0.93 & 0.66 \\
\hline Analyst coverage & 26.36 & 5.54 \\
\hline Idiosyncratic volatility & 42.81 & 72.49 \\
\hline Number of zero trading days & 5.80 & 0.44 \\
\hline Proportion of institutional holding (\%) & 4.10 & 49.84 \\
\hline
\end{tabular}

Notes: Each number is calculated as follows. First, we calculate the average value of all the firms in each month in the period from May 2002 to December 2016; second, we compute the time-series average of those values. Market value is in natural log form (in million US\$). The figures for the US market are calculated based on data from the CRSP, Compustat, IBES and Thomson Reuters.

Table 2: Descriptive statistics

\begin{tabular}{|l|l|l|l|l|l|l|l|}
\hline & mean & SD & MIN & first quartile & median & third quartile & MAX \\
\hline Ret & 1.850 & 10.700 & -28.704 & -4.569 & 2.154 & 7.954 & 36.092 \\
\hline IVOL & 42.808 & 10.918 & 25.175 & 34.918 & 40.351 & 48.562 & 65.970 \\
\hline Close & 10.475 & 4.030 & 3.985 & 7.441 & 9.881 & 13.470 & 24.159 \\
\hline ILLIQ & 0.260 & 0.321 & 0.018 & 0.045 & 0.088 & 0.432 & 1.135 \\
\hline Turnover & 0.455 & 0.215 & 0.138 & 0.278 & 0.412 & 0.620 & 0.926 \\
\hline InstHld & 4.104 & 1.715 & 1.327 & 2.677 & 3.720 & 5.818 & 6.951 \\
\hline ZeroTrade & 5.799 & 4.911 & 1.829 & 2.721 & 4.792 & 5.902 & 23.998 \\
\hline Cov & 26.359 & 17.166 & 0.610 & 6.500 & 34.541 & 41.530 & 45.642 \\
\hline CVOL & 4.406 & 0.309 & 3.563 & 4.159 & 4.330 & 4.578 & 4.970 \\
\hline InstNum & 19.862 & 14.236 & 2.737 & 5.782 & 15.577 & 32.043 & 54.100 \\
\hline
\end{tabular}

Notes: Ret represents the rate of return of the stocks noted in percentage; IVOL represents the standard deviation of the residual values estimated for each stock per month based on the Fama-French three-factor model of the first 36 months; and Close represents the closing price of individual stocks. ILLIQ adopts the illiquidity indicator by Amihud (2002), a monthly calculation that involves dividing the absolute value of the daily rate of return for the past year by the average of the trading volume. The variable Turnover refers to the turnover rate, a monthly calculation of the average turnover rate for the past 12 months; InstHld refers to the institutional investors' shareholding ratio; ZeroTrade is the number of days that the stock has not been traded within the past 12 months; Cov is the number of analyst forecast reports published over the past year; $C V O L$ represents the cash flow volatility, which is the standard deviation of the operating cash flow over the past five years divided by the total asset ratio; and InstNum is the number of institutional investors, meaning the number of institutional investors holding the stock. 
Table 3: Correlation coefficients

\begin{tabular}{|c|c|c|c|c|c|c|c|c|c|}
\hline & Ret & IVOL & Close & ILLIQ & Turnover & Inst_Hld & $\begin{array}{l}\text { Zero_Trad } \\
\text { e }\end{array}$ & $\mathrm{COV}$ & CVOL \\
\hline IVOL & $\begin{array}{l}-0.030 * * \\
*\end{array}$ & & & & & & & & \\
\hline Close & $-0.023^{*}$ & $\begin{array}{l}0.160 * * \\
*\end{array}$ & & & & & & & \\
\hline ILLIQ & $\begin{array}{l}0.035 * * \\
*\end{array}$ & 0.002 & $\begin{array}{l}-0.110 * * \\
*\end{array}$ & & & & & & \\
\hline Turnover & $-0.023 * *$ & $\begin{array}{l}0.387 * * \\
*\end{array}$ & $\begin{array}{l}-0.084 * * \\
*\end{array}$ & $\begin{array}{l}-0.110 * * \\
*\end{array}$ & & & & & \\
\hline InstHld & -0.004 & $\begin{array}{l}0.042 * * \\
*\end{array}$ & $\begin{array}{l}0.453 * * \\
*\end{array}$ & $\begin{array}{l}-0.188 * * \\
*\end{array}$ & $\begin{array}{l}-0.185 * * \\
*\end{array}$ & & & & \\
\hline $\begin{array}{l}\text { ZeroTrad } \\
\mathrm{e}\end{array}$ & 0.005 & $\begin{array}{l}0.129 * * \\
*\end{array}$ & $\begin{array}{l}0.034 * * \\
*\end{array}$ & $0.115 * * *$ & $\begin{array}{l}0.020 * * \\
*\end{array}$ & $\begin{array}{l}0.016 * * \\
*\end{array}$ & & & \\
\hline Cov & -0.007 & $\begin{array}{l}-0.034 * * \\
*\end{array}$ & $\begin{array}{l}0.429 * * \\
*\end{array}$ & $\begin{array}{l}-0.278 * * \\
*\end{array}$ & $\begin{array}{l}-0.216 * * \\
*\end{array}$ & $\begin{array}{l}0.583 * * \\
*\end{array}$ & 0.011 & & \\
\hline CVOL & -0.002 & $\begin{array}{l}0.098 * * \\
*\end{array}$ & $\begin{array}{l}0.024 * * \\
*\end{array}$ & $0.06 * * *$ & $\begin{array}{l}0.038 * * \\
*\end{array}$ & $\begin{array}{l}-0.021 * * \\
*\end{array}$ & $0.036 * * *$ & $\begin{array}{l}-0.014 * * \\
*\end{array}$ & \\
\hline InstNum & -0.019 & $\begin{array}{l}-0.034 * * \\
*\end{array}$ & $\begin{array}{l}0.456 * * \\
*\end{array}$ & $\begin{array}{l}-0.311 * * \\
*\end{array}$ & $\begin{array}{l}-0.251 * * \\
*\end{array}$ & $\begin{array}{l}0.692 * * \\
*\end{array}$ & $-0.011 * *$ & $\begin{array}{l}0.776 * * \\
*\end{array}$ & $\begin{array}{l}-0.012 * * \\
*\end{array}$ \\
\hline
\end{tabular}

Notes: This table shows Pearson correlation coefficients among variables. We first compute the correlation in each, and then obtain the time-series average. Ret represents the rate of return of the stocks noted in percentage; IVOL represents the standard deviation of the residual values estimated for each stock per month based on the Fama-French three-factor model of the first 36 months; and Close represents the closing price of individual stocks. ILLIQ adopts the illiquidity indicator by Amihud (2002), a monthly calculation that involves dividing the absolute value of the daily rate of return for the past year by the average of the trading volume. The variable Turnover refers to the turnover rate, a monthly calculation of the average turnover rate for the past 12 months; InstHld refers to the institutional investors' shareholding ratio; ZeroTrade is the number of days that the stock has not been traded within the past 12 months; Cov is the number of analyst forecast reports published over the past year; $C V O L$ represents the cash flow volatility, which is the standard deviation of the operating cash flow over the past five years divided by the total asset ratio; and InstNum is the number of institutional investors, meaning the number of institutional investors holding the stock. ***, *** represent the significance at the $1 \%$, $5 \%$, and $10 \%$ levels, respectively. 
Table 4: Arbitrage risk and stock returns

Notes: This table shows the Fama-MacBeth regression result of arbitrage risk on stock returns. We first run the cross-sectional regression for each month and then we compute the time-series mean of the coefficients and the adjusted $R$-squared statistic. Then, we compute the time-series averages of each coefficient and its corresponding $t$-statistic (values in the parenthesis), and the adjusted $R$-squared statistic. Ret represents the rate of return of the stocks noted in percentage; IVOL represents the standard deviation of the residual values estimated for each stock per month based on the Fama-French three-factor model of the first 36 months; and Close represents the closing price of individual stocks. ILLIQ adopts the illiquidity indicator by Amihud (2002), a monthly calculation that involves dividing the absolute value of the daily rate of return for the past year by the average of the trading volume. The variable Turnover refers to the turnover rate, a monthly calculation of the average turnover rate for the past 12 months; InstHld refers to the institutional investors' shareholding ratio; ZeroTrade is the number of days that the stock has not been traded within the past 12 months; Cov is the number of analyst forecast reports published over the past year; CVOL represents the cash flow volatility, which is the standard deviation of the operating cash flow over the past five years divided by the total asset ratio; and InstNum is the number of institutional investors, meaning the number of institutional investors holding the stock. $* * *, * * *$ represent the significance at the $1 \%, 5 \%$, and $10 \%$ levels, respectively.

\begin{tabular}{|c|c|c|c|c|c|c|}
\hline & $(1)$ & $(2)$ & $(3)$ & $(4)$ & $(5)$ & $(6)$ \\
\hline \multirow[t]{2}{*}{ Intercept } & $4.710 * * *$ & $4.391 * * *$ & $1.994 * *$ & $4.607 * * *$ & $4.702 * * *$ & $4.899 * * *$ \\
\hline & $(3.96)$ & $(3.30)$ & $(2.03)$ & $(3.62)$ & $(4.03)$ & $(3.91)$ \\
\hline \multirow[t]{2}{*}{ IVOL $_{t-1}$} & $-0.285 * * *$ & & $>$ & $-0.380 *$ & $-0.739 * * *$ & $-0.120 *$ \\
\hline & $(-2.74)$ & & +1 & $(-2.40)$ & $(-2.69)$ & $(-1.92)$ \\
\hline \multirow[t]{2}{*}{ Close $_{t-1}$} & & $-0.595 *$ & 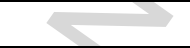 & $-0.560 *$ & & $-0.787 * *$ \\
\hline & & $(-1.76)$ & + & $(-1.86)$ & & $(-2.35)$ \\
\hline \multirow[t]{2}{*}{ ILLIQ $_{\mathrm{t}-1}$} & & 0.204 & $\mathrm{Y}$ & 0.207 & & $0.426 * * *$ \\
\hline & & $(1.29)$ & + & $(1.32)$ & & $(2.91)$ \\
\hline \multirow[t]{2}{*}{ Turnover $_{\mathrm{t}-1}$} & & $-1.538 * *$ & + & $-1.615 * * *$ & & $-1.231 * *$ \\
\hline & & $(-2.15)$ & & $(-2.67)$ & & $(-2.09)$ \\
\hline \multirow[t]{2}{*}{ InstHld $_{\mathrm{t}-1}$} & & $0.083^{*}$ & & $0.086^{*}$ & & $-0.092 *$ \\
\hline & & $(1.86)$ & & $(1.95)$ & & $(-1.96)$ \\
\hline \multirow[t]{2}{*}{ ZeroTrade $_{\mathrm{t}-1}$} & & -0.053 & & -0.047 & & -0.046 \\
\hline & & $(-0.50)$ & & $(-1.45)$ & & $(-0.46)$ \\
\hline \multirow[t]{2}{*}{$\mathrm{COV}_{\mathrm{t}-1}$} & & $\nabla+$ & $0.179 *$ & & $0.182 *$ & $0.201 * * *$ \\
\hline & & & $(1.95)$ & & $(1.85)$ & $(2.63)$ \\
\hline \multirow[t]{2}{*}{$\mathrm{CVOL}_{\mathrm{t}-1}$} & & & $0.511 * *$ & & $0.533 * *$ & $0.664 *$ \\
\hline & & & $(2.15)$ & & $(1.98)$ & $(1.82)$ \\
\hline \multirow[t]{2}{*}{ InstNum $_{\mathrm{t}-1}$} & 1 & & $-0.169 *$ & & $-0.199 *$ & $0.192 *$ \\
\hline & + & & $(-1.79)$ & & $(-1.84)$ & $(1.96)$ \\
\hline Adjust $\mathrm{R}^{2}$ & $12.10 \%$ & $17.70 \%$ & $14.01 \%$ & $18.00 \%$ & $15.17 \%$ & $29.02 \%$ \\
\hline
\end{tabular}


Table 5: The expected slope of out-of-sample forecast returns

\begin{tabular}{|l|l|l|l|l|}
\hline \multicolumn{2}{|l|}{ Panel A: Prediction of rolling 12 months (from Jun 2004 to Dec 2016) } \\
\hline Strategy & $\bar{\beta}$ & Standard deviation & t-statistic & Adjusted $R^{2}$ \\
\hline 1 & 1.327 & 7.781 & 1.70 & $15.08 \%$ \\
\hline 2 & 0.204 & 2.126 & 1.15 & $21.36 \%$ \\
\hline 3 & 0.158 & 1.908 & 1.00 & $23.24 \%$ \\
\hline 4 & 0.332 & 1.471 & 2.72 & $19.97 \%$ \\
\hline Panel B: Prediction of rolling 24 months (from Jun 2005 to Dec 2016) & Adjusted $R^{2}$ \\
\hline Strategy & $\bar{\beta}$ & Standard deviation & $t$-statistic & $18.12 \%$ \\
\hline 1 & 1.224 & 8.761 & 1.46 & $24.39 \%$ \\
\hline 2 & 0.527 & 1.942 & 3.13 & $21.20 \%$ \\
\hline 3 & 0.512 & 1.867 & 3.16 & $20.33 \%$ \\
\hline 4 & 0.398 & 1.611 & 2.85 & \\
\hline Panel C: Prediction of rolling 36 months (from Jun 2006 to Dec 2016$)$ & Adjusted $R^{2}$ \\
\hline Strategy & $\bar{\beta}$ & Standard deviation & $t$-statistic & $18.14 \%$ \\
\hline 1 & 1.178 & 4.344 & 3.00 & $18.50 \%$ \\
\hline 2 & 0.613 & 2.114 & 3.17 & $19.50 \%$ \\
\hline 3 & 0.617 & 2.017 & 3.38 & $19.66 \%$ \\
\hline 4 & 0.496 & 1.848 & 2.97 & \\
\hline
\end{tabular}

Notes: In this table we test the effectiveness of the out-of-sample expected returns for four trading strategies. We run the Fama-MacBeth cross-section regression specified as $R_{i, t}=a_{t}+\beta_{t} \widehat{R_{l, t}}+\epsilon_{i, t}$. Panel A reports the average of forecasting beta for a 12-month moving holding period, Panel B for 24-month and Panel C for 36-month. 
Table 6: The rates of return after adjusting the risks of investment strategies Notes: Based on the out-of-sample expected returns for four trading strategies and the momentum trading strategy (PM), we sort stocks into 10 groups, with group 1 containing loser stocks and group 10 containing winner stocks. We then construct a zero-cost long-short portfolio by longing winner stocks and shorting loser stocks. The portfolios are held for 1, 3, 6 and 12 months, respectively. We use the Fama-French three-factor and five-factor models to obtain abnormal returns. Panel A reports the results for the 3-month, Panel B for 6-month. $* * *, * *, *$ represent the significance at the $1 \%, 5 \%$, and $10 \%$ levels, respectively.

\begin{tabular}{|c|c|c|c|c|c|c|c|c|c|c|}
\hline \multicolumn{11}{|c|}{ Panel A: 3-month formation period } \\
\hline & \multicolumn{5}{|c|}{ 1-month holding period } & \multicolumn{5}{|c|}{ 3-month holding period } \\
\hline & S1 & S2 & S3 & S4 & PM & S1 & S2 & S3 & S4 & PM \\
\hline$\alpha_{\mathrm{FF} 3}$ & $\begin{array}{l}1.373 * \\
* *\end{array}$ & $\begin{array}{l}1.244 \\
* *\end{array}$ & $1.36^{* *}$ & $0.927 *$ & $\begin{array}{l}-1.455 \\
* *\end{array}$ & $\begin{array}{l}1.398 * \\
* *\end{array}$ & $\begin{array}{l}1.310 \\
* *\end{array}$ & $\begin{array}{l}1.392 * \\
* *\end{array}$ & $\begin{array}{l}1.096^{*} \\
*\end{array}$ & $\begin{array}{l}-1.246 \\
* *\end{array}$ \\
\hline$)^{t\left(\alpha_{F F}\right.}$ & $\begin{array}{l}(3.288 \\
) \\
\end{array}$ & $\begin{array}{l}(2.27 \\
6) \\
\end{array}$ & $\begin{array}{l}(2.583 \\
)\end{array}$ & $\begin{array}{l}(1.757 \\
\end{array}$ & $\begin{array}{l}(-2.212 \\
)^{2}\end{array}$ & $\begin{array}{l}(3.548 \\
)\end{array}$ & $\begin{array}{l}(2.50 \\
7)\end{array}$ & $\begin{array}{l}(2.724 \\
\end{array}$ & $\begin{array}{l}(2.163 \\
)\end{array}$ & $\begin{array}{l}(-2.279 \\
)\end{array}$ \\
\hline$\alpha_{\mathrm{FF} 5}$ & $\begin{array}{l}1.118^{*} \\
*\end{array}$ & $\begin{array}{l}0.925 \\
* \\
\end{array}$ & $\begin{array}{l}1.851 * \\
* *\end{array}$ & $\begin{array}{l}1.434 * \\
*\end{array}$ & $\begin{array}{l}-1.601 \\
* *\end{array}$ & $\begin{array}{l}1.178^{*} \\
* *\end{array}$ & $\begin{array}{l}0.955 \\
*\end{array}$ & $\begin{array}{l}1.837 * \\
* *\end{array}$ & $\begin{array}{l}1.559 * \\
* *\end{array}$ & $\begin{array}{l}-1.415 \\
* * \\
\end{array}$ \\
\hline \multirow[t]{3}{*}{$\begin{array}{l}\mathrm{t}\left(\alpha_{\mathrm{FF}}\right. \\
\text { 5) }\end{array}$} & $\begin{array}{l}(2.598 \\
)\end{array}$ & $\begin{array}{l}(1.68 \\
5)\end{array}$ & $(3.36)$ & $\begin{array}{l}(2.601 \\
)\end{array}$ & $\begin{array}{l}(-2.326 \\
)\end{array}$ & $\begin{array}{l}(2.901 \\
)^{2}\end{array}$ & $\begin{array}{l}(1.83 \\
1)\end{array}$ & $\begin{array}{l}(3.421 \\
{ }^{2}\end{array}$ & $\begin{array}{l}(2.934 \\
{ }^{2}\end{array}$ & $\begin{array}{l}(-2.497 \\
\end{array}$ \\
\hline & \multicolumn{5}{|c|}{ 6-month holding period } & \multicolumn{5}{|c|}{ 12-month holding period } \\
\hline & S1 & S2 & S3 & S4 & PM & S1 & S2 & S3 & S4 & PM \\
\hline$\alpha_{\mathrm{FF3}}$ & $\begin{array}{l}1.323 * \\
* *\end{array}$ & $\begin{array}{l}1.292 \\
* * \\
\end{array}$ & $\begin{array}{l}1.390 * \\
* *\end{array}$ & $\begin{array}{l}1.036^{*} \\
*\end{array}$ & $\begin{array}{l}-0.751 \\
* * \\
\end{array}$ & $\begin{array}{l}0.995^{*} \\
*\end{array}$ & 0.128 & $\begin{array}{l}1.064 * \\
*\end{array}$ & 0.729 & $\begin{array}{l}-0.436 \\
* \\
\end{array}$ \\
\hline$t\left(\alpha_{\mathrm{FF}}\right.$ & $\begin{array}{l}(3.460 \\
{ }^{2}\end{array}$ & $\begin{array}{l}\text { (2.44 } \\
9)\end{array}$ & $\begin{array}{l}(2.686 \\
{ }^{2}\end{array}$ & $\begin{array}{l}(2.002 \\
)\end{array}$ & $\begin{array}{l}(-2.001 \\
{ }^{2}\end{array}$ & $\begin{array}{l}(2.022 \\
)\end{array}$ & $\begin{array}{l}(0.25 \\
9)\end{array}$ & $\begin{array}{l}(2.182 \\
)\end{array}$ & $\begin{array}{l}(1.461 \\
{ }^{2}\end{array}$ & $\begin{array}{l}(-1.772 \\
)^{2}\end{array}$ \\
\hline$\alpha_{\mathrm{FF} 5}$ & $\begin{array}{l}1.142 * \\
* *\end{array}$ & $\begin{array}{l}0.959 \\
* \\
\end{array}$ & $\begin{array}{l}1.835 * \\
* *\end{array}$ & $\begin{array}{l}1.519 * \\
* *\end{array}$ & $\begin{array}{l}-0.986 \\
* *\end{array}$ & 0.756 & 0.645 & $\begin{array}{l}1.417 * \\
* *\end{array}$ & $\begin{array}{l}1.124 * \\
*\end{array}$ & $\begin{array}{l}-0.481 \\
*\end{array}$ \\
\hline $\begin{array}{l}\mathrm{t}\left(\alpha_{\mathrm{FF}}\right. \\
\text { 5) }\end{array}$ & $\begin{array}{l}(2.887 \\
)\end{array}$ & $\begin{array}{l}\text { (1.80 } \\
9) \\
\end{array}$ & $\begin{array}{l}(3.349 \\
)\end{array}$ & $\begin{array}{l}(2.782 \\
)\end{array}$ & $\begin{array}{l}(-2.572 \\
)\end{array}$ & )$^{(1.503}$ & $\begin{array}{l}(1.18 \\
8)\end{array}$ & $(2.63)$ & )$^{(2.043}$ & $\begin{array}{l}(-1.877 \\
)^{2}\end{array}$ \\
\hline \multicolumn{11}{|c|}{ B: 6-month formation period } \\
\hline & \multicolumn{5}{|c|}{ 1-month holding period } & \multicolumn{5}{|c|}{ 3-month holding period } \\
\hline & S1 & S2 & S3 & S4 & PM & S1 & S2 & S3 & S4 & PM \\
\hline$\alpha_{\mathrm{FF} 3}$ & $\begin{array}{l}1.271 * \\
* *\end{array}$ & $\begin{array}{l}1.375 \\
* *\end{array}$ & $\begin{array}{l}1.472 * \\
* *\end{array}$ & $\begin{array}{l}1.158 * \\
*\end{array}$ & $\begin{array}{l}-1.988 \\
* * *\end{array}$ & $\begin{array}{l}1.191 * \\
* *\end{array}$ & $\begin{array}{l}1.385 \\
* *\end{array}$ & $\begin{array}{l}1.443 * \\
* *\end{array}$ & $\begin{array}{l}1.119 * \\
*\end{array}$ & $\begin{array}{l}-1.343 \\
* * \\
\end{array}$ \\
\hline$)^{t}\left(\alpha_{\mathrm{FF}}\right.$ & $\begin{array}{l}(3.045 \\
)\end{array}$ & $\begin{array}{l}(2.52 \\
7)\end{array}$ & $\begin{array}{l}(2.743 \\
)\end{array}$ & )$^{(2.191}$ & $\begin{array}{l}(-3.091 \\
)^{2}\end{array}$ & $\begin{array}{l}(3.027 \\
)\end{array}$ & $\begin{array}{l}(2.54 \\
2)\end{array}$ & $\begin{array}{l}(2.692 \\
)^{2}\end{array}$ & $\begin{array}{l}(2.132 \\
)\end{array}$ & $\begin{array}{l}(-2.326 \\
)^{2}\end{array}$ \\
\hline$\alpha_{\mathrm{FF} 5}$ & $\begin{array}{l}1.114 * \\
*\end{array}$ & $\begin{array}{l}1.023 \\
* \\
\end{array}$ & $\begin{array}{l}1.855^{*} \\
* *\end{array}$ & $\begin{array}{l}1.630 * \\
* *\end{array}$ & $\begin{array}{l}-2.261 \\
* * *\end{array}$ & $\begin{array}{l}0.958 * \\
*\end{array}$ & $\begin{array}{l}1.046 \\
*\end{array}$ & $\begin{array}{l}1.870^{*} \\
* *\end{array}$ & $\begin{array}{l}1.578^{*} \\
* *\end{array}$ & $\begin{array}{l}-1.679 \\
* * *\end{array}$ \\
\hline $\begin{array}{l}t\left(\alpha_{\mathrm{FF}}\right. \\
5)\end{array}$ & $\begin{array}{l}(2.568 \\
)\end{array}$ & $\begin{array}{l}(1.87 \\
6) \\
\end{array}$ & $\begin{array}{l}(3.254 \\
\end{array}$ & $\begin{array}{l}(2.927 \\
)\end{array}$ & $\begin{array}{l}(-3.392 \\
)\end{array}$ & $\begin{array}{l}(2.372 \\
)\end{array}$ & $\begin{array}{l}\text { (1.90 } \\
9)\end{array}$ & $\begin{array}{l}(3.285 \\
)\end{array}$ & $\begin{array}{l}(2.843 \\
)\end{array}$ & )$^{(-2.831}$ \\
\hline & \multicolumn{5}{|c|}{ 6-month holding period } & \multicolumn{5}{|c|}{ 12-month holding period } \\
\hline$\alpha_{\mathrm{FF} 3}$ & $\begin{array}{l}1.219 * \\
* *\end{array}$ & $\begin{array}{l}1.198 \\
* *\end{array}$ & $1^{2} 281^{*}$ & $0.907 *$ & -0.697 & $\begin{array}{l}1.090 * \\
* *\end{array}$ & $\begin{array}{l}1.099 \\
* *\end{array}$ & $1.164^{*}$ & 0.820 & $\begin{array}{l}-0.601 \\
*\end{array}$ \\
\hline$)^{t}\left(\alpha_{F F}\right.$ & $\begin{array}{l}(3.205 \\
)\end{array}$ & $\begin{array}{l}(2.22 \\
4) \\
\end{array}$ & $\begin{array}{l}(2.406 \\
)\end{array}$ & $\begin{array}{l}(1.692 \\
)\end{array}$ & $\begin{array}{l}(-1.494 \\
)\end{array}$ & $\begin{array}{l}(2.901 \\
)\end{array}$ & $\begin{array}{l}(2.14 \\
7) \\
\end{array}$ & $\begin{array}{l}(2.303 \\
)\end{array}$ & $\begin{array}{l}(1.595 \\
{ }^{2}\end{array}$ & $\begin{array}{l}(-1.822 \\
{ }^{2}\end{array}$ \\
\hline$\alpha_{\mathrm{FF} 5}$ & $\begin{array}{l}1.029 * \\
* *\end{array}$ & 0.885 & $\begin{array}{l}1.736^{*} \\
* *\end{array}$ & $\begin{array}{l}1.428 * \\
*\end{array}$ & $\begin{array}{l}-0.924 \\
*\end{array}$ & $\begin{array}{l}0.973 * \\
*\end{array}$ & 0.800 & $\begin{array}{l}1.611 * \\
* *\end{array}$ & $\begin{array}{l}1.296^{*} \\
*\end{array}$ & $\begin{array}{l}-0.700 \\
* *\end{array}$ \\
\hline $\begin{array}{l}\text { t }\left(\alpha_{\mathrm{FF}}\right. \\
\text { 5) }\end{array}$ & $\begin{array}{l}(2.630 \\
)^{2}\end{array}$ & $\begin{array}{l}(1.62 \\
7) \\
\end{array}$ & $\begin{array}{l}(3.055 \\
)\end{array}$ & $\begin{array}{l}(2.509 \\
)^{2}\end{array}$ & $\begin{array}{l}(-1.927 \\
{ }^{2}\end{array}$ & $\begin{array}{l}(2.493 \\
)\end{array}$ & $\begin{array}{l}(1.52 \\
5) \\
\end{array}$ & $\begin{array}{l}(2.893 \\
)^{2}\end{array}$ & $\begin{array}{l}(2.289 \\
)\end{array}$ & $\begin{array}{l}(-2.037 \\
{ }^{2}\end{array}$ \\
\hline
\end{tabular}

Table 7: Robustness analysis

\begin{tabular}{|c|c|c|c|c|c|c|c|c|c|c|c|c|}
\hline & \multicolumn{4}{|c|}{$\begin{array}{l}\text { Prediction (rolling } 12 \\
\text { months) }\end{array}$} & \multicolumn{4}{|c|}{$\begin{array}{l}\text { Prediction (rolling } 36 \\
\text { months) }\end{array}$} & \multicolumn{4}{|c|}{$\begin{array}{l}\text { Information (Jan } \\
\text { excluded) }\end{array}$} \\
\hline & $\mathrm{K}=1$ & $\mathrm{~K}=3$ & $\mathrm{~K}=6$ & $\begin{array}{l}\mathrm{K}=1 \\
2\end{array}$ & $\mathrm{~K}=1$ & $K=3$ & $\mathrm{~K}=6$ & $\mathrm{~K}=12$ & $\mathrm{~K}=1$ & $\mathrm{~K}=3$ & $\mathrm{~K}=6$ & $\begin{array}{l}\mathrm{K}=1 \\
2\end{array}$ \\
\hline $\begin{array}{l}S \\
1\end{array}$ & 0.706 & $\begin{array}{l}1.054 \\
* *\end{array}$ & $\begin{array}{l}0.921 \\
*\end{array}$ & $\begin{array}{l}0.72 \\
9 *\end{array}$ & $\begin{array}{l}1.144 \\
*\end{array}$ & $\begin{array}{l}1.127 \\
*\end{array}$ & 0.511 & 0.848 & $\begin{array}{l}1.02 \\
2^{*}\end{array}$ & $\begin{array}{l}1.12 \\
3 * *\end{array}$ & $\begin{array}{l}1.06 \\
1 *\end{array}$ & $\begin{array}{l}0.95 \\
4 *\end{array}$ \\
\hline
\end{tabular}




\begin{tabular}{|c|c|c|c|c|c|c|c|c|c|c|c|c|}
\hline & ${ }^{(1.109}$ & $\begin{array}{l}\text { (2.15 } \\
2)\end{array}$ & $\begin{array}{l}(1.89 \\
3)\end{array}$ & $\begin{array}{l}(1.63 \\
2)\end{array}$ & $\begin{array}{l}(1.94 \\
1)\end{array}$ & $\begin{array}{l}(1.92 \\
2)\end{array}$ & $\begin{array}{l}(1.14 \\
6)\end{array}$ & $\begin{array}{l}(1.37 \\
4)\end{array}$ & $\begin{array}{l}(1.93 \\
1)\end{array}$ & $\begin{array}{l}(1.96 \\
1)\end{array}$ & $\begin{array}{l}(1.93 \\
9)\end{array}$ & $\begin{array}{l}(1.88 \\
2)\end{array}$ \\
\hline$S$ & 1.107 & 1.282 & 1.471 & 1.31 & 1.924 & 2.139 & 1.425 & 1.241 & 1.47 & 1.56 & 1.50 & 1.49 \\
\hline \multirow[t]{2}{*}{2} & & $* *$ & $* * *$ & $1 * *$ & $* * *$ & $* * *$ & $* *$ & $*$ & $2 * *$ & $2 * *$ & $2 * *$ & $3 * *$ \\
\hline & $(2.173$ & $\begin{array}{l}\text { (2.24 } \\
7)\end{array}$ & $\begin{array}{l}\text { (2.79 } \\
3)\end{array}$ & $\begin{array}{l}(2.23 \\
0)\end{array}$ & $\begin{array}{l}(2.87 \\
1)\end{array}$ & $\begin{array}{l}(2.97 \\
4)\end{array}$ & $\begin{array}{l}(2.11 \\
2)\end{array}$ & $\begin{array}{l}(1.89 \\
2)\end{array}$ & $\begin{array}{l}\text { (2.10 } \\
4)\end{array}$ & $\begin{array}{l}\text { (2.26 } \\
3)\end{array}$ & $\begin{array}{l}(2.26 \\
5)\end{array}$ & $\begin{array}{l}\text { (2.23 } \\
7)\end{array}$ \\
\hline \multirow[t]{2}{*}{$\begin{array}{l}S \\
3 \\
\end{array}$} & $\begin{array}{l}1.088 \\
*\end{array}$ & $\begin{array}{l}1.072 \\
* *\end{array}$ & $\begin{array}{l}1.451 \\
* * *\end{array}$ & $\begin{array}{l}1.28 \\
1 * *\end{array}$ & $\begin{array}{l}1.934 \\
* * *\end{array}$ & $\begin{array}{l}2.125 \\
* * *\end{array}$ & $\begin{array}{l}1.362 \\
* *\end{array}$ & $\begin{array}{l}1.234 \\
* *\end{array}$ & $\begin{array}{l}1.71 \\
3 * *\end{array}$ & $\begin{array}{l}1.64 \\
4 * *\end{array}$ & $\begin{array}{l}1.62 \\
7 * *\end{array}$ & $\begin{array}{l}1.52 \\
4 * *\end{array}$ \\
\hline & )$^{(1.837}$ & $\begin{array}{l}(1.96 \\
4)\end{array}$ & $\begin{array}{l}(2.69 \\
1)\end{array}$ & $\begin{array}{l}(2.21 \\
1)\end{array}$ & $\begin{array}{l}(2.73 \\
5)\end{array}$ & $\begin{array}{l}(3.12 \\
0)\end{array}$ & $\begin{array}{l}(2.13 \\
3)\end{array}$ & $\begin{array}{l}(2.14 \\
5)\end{array}$ & $\begin{array}{l}\text { (2.30 } \\
9)\end{array}$ & $\begin{array}{l}(2.41 \\
7)\end{array}$ & $\begin{array}{l}(2.32 \\
0)\end{array}$ & $\begin{array}{l}\text { (2.10 } \\
\text { 2) }\end{array}$ \\
\hline \multirow[t]{2}{*}{$\begin{array}{l}S \\
4 \\
\end{array}$} & $\begin{array}{l}1.216 \\
*\end{array}$ & $\begin{array}{l}1.031 \\
*\end{array}$ & $\begin{array}{l}1.189 \\
* *\end{array}$ & $\begin{array}{l}1.13 \\
7 * *\end{array}$ & $\begin{array}{l}1.627 \\
* *\end{array}$ & $\begin{array}{l}1.723 \\
* *\end{array}$ & $\begin{array}{l}1.103 \\
*\end{array}$ & $\begin{array}{l}1.075 \\
* *\end{array}$ & $\begin{array}{l}1.26 \\
7 * *\end{array}$ & $\begin{array}{l}1.21 \\
9 *\end{array}$ & $\begin{array}{l}1.18 \\
8 * *\end{array}$ & $\begin{array}{l}1.33 \\
3 * *\end{array}$ \\
\hline & $\begin{array}{l}(1.913 \\
)^{2}\end{array}$ & $\begin{array}{l}(1.83 \\
7)\end{array}$ & $\begin{array}{l}(2.23 \\
1)\end{array}$ & $\begin{array}{l}\text { (2.28 } \\
1)\end{array}$ & $\begin{array}{l}\text { (2.23 } \\
3)\end{array}$ & $\begin{array}{l}(2.36 \\
3)\end{array}$ & $\begin{array}{l}(1.95 \\
9)\end{array}$ & $\begin{array}{l}(2.13 \\
5)\end{array}$ & $\begin{array}{l}(1.97 \\
2)\end{array}$ & $\begin{array}{l}(1.86 \\
0)\end{array}$ & $\begin{array}{l}\text { (1.96 } \\
3)\end{array}$ & $\begin{array}{l}\text { (2.01 } \\
5)\end{array}$ \\
\hline \multirow[t]{4}{*}{$\begin{array}{l}\mathrm{P} \\
\mathrm{M}\end{array}$} & -0.141 & 0.297 & 0.420 & $\begin{array}{l}0.40 \\
7 * *\end{array}$ & $\begin{array}{l}-0.53 \\
0\end{array}$ & 0.002 & 0.121 & $\begin{array}{l}0.618 \\
*\end{array}$ & $\begin{array}{l}-0.33 \\
0\end{array}$ & $\begin{array}{l}0.37 \\
9\end{array}$ & $\begin{array}{l}0.13 \\
7\end{array}$ & $\begin{array}{l}0.47 \\
8 * *\end{array}$ \\
\hline & $\begin{array}{l}(-0.23 \\
1)\end{array}$ & $\begin{array}{l}(0.62 \\
1)\end{array}$ & $\begin{array}{l}(1.02 \\
2)\end{array}$ & $\begin{array}{l}(2.23 \\
1)\end{array}$ & $\begin{array}{l}(-0.62 \\
1)\end{array}$ & $\begin{array}{l}(0.00 \\
1)\end{array}$ & $\begin{array}{l}(0.33 \\
9) \\
\end{array}$ & $\begin{array}{l}(1.92 \\
0)\end{array}$ & $\begin{array}{l}(-0.3 \\
60) \\
\end{array}$ & $\begin{array}{l}(0.54 \\
3)\end{array}$ & $\begin{array}{l}(0.53 \\
7) \\
\end{array}$ & $\begin{array}{l}(2.02 \\
1)\end{array}$ \\
\hline & \multicolumn{4}{|c|}{$\begin{array}{l}\text { Small Size ( } 30 \% \text { of the } \\
\text { sample) }\end{array}$} & \multicolumn{4}{|c|}{$\begin{array}{l}\text { Middle Size ( } 40 \% \text { of the } \\
\text { sample) }\end{array}$} & \multicolumn{4}{|c|}{$\begin{array}{l}\text { Large Size }(30 \% \text { of the } \\
\text { sample) }\end{array}$} \\
\hline & $K=1$ & $K=3$ & $K=6$ & $\begin{array}{l}\mathrm{K}=1 \\
2\end{array}$ & $K=1$ & $K=3$ & $K=6$ & $\mathrm{~K}=12$ & $\mathrm{~K}=1$ & $\mathrm{~K}=3$ & $K=6$ & $\begin{array}{l}\mathrm{K}=1 \\
2\end{array}$ \\
\hline \multirow[t]{2}{*}{$\begin{array}{l}S \\
1 \\
\end{array}$} & $\begin{array}{l}2.136 \\
* * * \\
\end{array}$ & $\begin{array}{l}1.262 \\
* * * \\
\end{array}$ & $\begin{array}{l}0.928 \\
* * *\end{array}$ & $\begin{array}{l}0.62 \\
4 * \\
\end{array}$ & $\begin{array}{l}1.311 \\
* * *\end{array}$ & $\begin{array}{l}1.062 \\
* *\end{array}$ & $\begin{array}{l}0.875 \\
* \quad \\
\end{array}$ & 0.267 & $\begin{array}{l}0.26 \\
0 \\
\end{array}$ & $\begin{array}{l}0.64 \\
1 \\
\end{array}$ & $\begin{array}{l}0.69 \\
2 \\
\end{array}$ & $\begin{array}{l}0.97 \\
2^{*} \\
\end{array}$ \\
\hline & $\begin{array}{l}(5.828 \\
)\end{array}$ & $\begin{array}{l}(4.25 \\
2) \\
\end{array}$ & $\begin{array}{l}(3.01 \\
2) \\
\end{array}$ & $\begin{array}{l}\text { (1.89 } \\
1)\end{array}$ & $\begin{array}{l}\text { (3.32 } \\
\text { 3) }\end{array}$ & $\begin{array}{l}\text { (2.13 } \\
6)\end{array}$ & $\begin{array}{l}(1.86 \\
2)\end{array}$ & $\begin{array}{l}(0.71 \\
2)\end{array}$ & $\begin{array}{l}(0.42 \\
2)\end{array}$ & $\begin{array}{l}(1.02 \\
2)\end{array}$ & $\begin{array}{l}(1.20 \\
1)\end{array}$ & $\begin{array}{l}\text { (1.68 } \\
\text { 2) }\end{array}$ \\
\hline \multirow[t]{2}{*}{$\begin{array}{l}S \\
2 \\
\end{array}$} & $\begin{array}{l}2.412 \\
* * *\end{array}$ & $\begin{array}{l}1.698 \\
* * *\end{array}$ & $\begin{array}{l}1.226 \\
* * *\end{array}$ & $\begin{array}{l}1.10 \\
2 *\end{array}$ & $\begin{array}{l}2.371 \\
* * *\end{array}$ & $\begin{array}{l}1.722 \\
* * *\end{array}$ & $\begin{array}{l}1.628 \\
* * *\end{array}$ & $\begin{array}{l}1.252 \\
* * *\end{array}$ & $\begin{array}{l}0.54 \\
4 \\
\end{array}$ & $\begin{array}{l}0.34 \\
7 \\
\end{array}$ & $\begin{array}{l}0.38 \\
2 \\
\end{array}$ & $\begin{array}{l}0.72 \\
0 \\
\end{array}$ \\
\hline & $\begin{array}{l}(4.789 \\
)\end{array}$ & $\begin{array}{l}\text { (3.62 } \\
9)\end{array}$ & $\begin{array}{l}(2.65 \\
\text { 2) }\end{array}$ & $\begin{array}{l}\text { (1.95 } \\
\text { 2) }\end{array}$ & $\begin{array}{l}\text { (3.01 } \\
\text { 2) }\end{array}$ & $\begin{array}{l}3.11 \\
0)\end{array}$ & $\begin{array}{l}\text { (3.21 } \\
1)\end{array}$ & $\begin{array}{l}2.83 \\
6) \\
\end{array}$ & $\begin{array}{l}(0.72 \\
1)\end{array}$ & $\begin{array}{l}(0.64 \\
1)\end{array}$ & $\begin{array}{l}(0.70 \\
2)\end{array}$ & $\begin{array}{l}\text { (1.24 } \\
\text { 2) }\end{array}$ \\
\hline \multirow[t]{2}{*}{$\begin{array}{l}S \\
3 \\
\end{array}$} & $\begin{array}{l}2.291 \\
* * *\end{array}$ & $\begin{array}{l}1.652 \\
* * *\end{array}$ & $\begin{array}{l}1.122 \\
* *\end{array}$ & $\begin{array}{l}1.01 \\
1 * \\
\end{array}$ & $\begin{array}{l}2.234 \\
* * *\end{array}$ & $\begin{array}{l}1.633 \\
* * *\end{array}$ & $\begin{array}{l}1.643 \\
* * *\end{array}$ & $\begin{array}{l}1.362 \\
* * *\end{array}$ & $\begin{array}{l}0.40 \\
2\end{array}$ & $\begin{array}{l}0.26 \\
1\end{array}$ & $\begin{array}{l}0.20 \\
4\end{array}$ & $\begin{array}{l}0.76 \\
1\end{array}$ \\
\hline & $\begin{array}{l}(4.548 \\
)^{2}\end{array}$ & $\begin{array}{l}\text { (3.21 } \\
0) \\
\end{array}$ & $\begin{array}{l}(2.32 \\
6) \\
\end{array}$ & $\begin{array}{l}(1.93 \\
2) \\
\end{array}$ & $\begin{array}{l}(3.29 \\
1) \\
\end{array}$ & $\begin{array}{l}3.21 \\
0) \\
\end{array}$ & $\begin{array}{l}\text { (3.71 } \\
1)\end{array}$ & $\begin{array}{l}\text { (3.11 } \\
7) \\
\end{array}$ & $\begin{array}{l}(0.69 \\
0)\end{array}$ & $\begin{array}{l}(0.86 \\
2)\end{array}$ & $\begin{array}{l}(0.41 \\
4)\end{array}$ & $\begin{array}{l}(1.27 \\
4)\end{array}$ \\
\hline \multirow[t]{2}{*}{$\begin{array}{l}S \\
4 \\
\end{array}$} & $\begin{array}{l}2.131 \\
* * *\end{array}$ & $\begin{array}{l}1.182 \\
* * *\end{array}$ & $\begin{array}{l}1.264 \\
*\end{array}$ & $\begin{array}{l}1.23 \\
1 * \\
\end{array}$ & $\begin{array}{l}2.013 \\
* * *\end{array}$ & $\begin{array}{l}1.677 \\
* * *\end{array}$ & $\begin{array}{l}1.471 \\
* * *\end{array}$ & $\begin{array}{l}1.332 \\
* * *\end{array}$ & $\begin{array}{l}0.23 \\
8 \\
\end{array}$ & $\begin{array}{l}0.21 \\
4 \\
\end{array}$ & $\begin{array}{l}0.27 \\
2 \\
\end{array}$ & $\begin{array}{l}0.82 \\
3 \\
\end{array}$ \\
\hline & $\begin{array}{l}(5.015 \\
)\end{array}$ & $\begin{array}{l}\text { (2.66 } \\
3)\end{array}$ & $\begin{array}{l}(1.88 \\
6) \\
\end{array}$ & $\begin{array}{l}(1.79 \\
6)\end{array}$ & $\begin{array}{l}(2.30 \\
6)\end{array}$ & $\begin{array}{l}(3.51 \\
6)\end{array}$ & $\begin{array}{l}(3.81 \\
2) \\
\end{array}$ & $\begin{array}{l}(3.48 \\
0)\end{array}$ & $\begin{array}{l}(0.32 \\
8)\end{array}$ & $\begin{array}{l}(0.23 \\
3)\end{array}$ & $\begin{array}{l}(0.58 \\
0)\end{array}$ & $\begin{array}{l}\text { (1.30 } \\
3)\end{array}$ \\
\hline \multirow[t]{2}{*}{$\begin{array}{l}\mathrm{P} \\
\mathrm{M} \\
\end{array}$} & $\begin{array}{l}-3.524 \\
* * *\end{array}$ & $\begin{array}{l}-0.82 \\
4 * * \\
\end{array}$ & $\begin{array}{l}-0.24 \\
2 \\
\end{array}$ & $\begin{array}{l}-0.21 \\
1\end{array}$ & $\begin{array}{l}-1.12 \\
8^{* *}\end{array}$ & 0.188 & $\begin{array}{l}0.522 \\
* *\end{array}$ & $\begin{array}{l}0.338 \\
* \\
\end{array}$ & $\begin{array}{l}0.21 \\
0 \\
\end{array}$ & $\begin{array}{l}0.34 \\
2 \\
\end{array}$ & $\begin{array}{l}0.04 \\
4 \\
\end{array}$ & $\begin{array}{l}0.53 \\
1 * \\
\end{array}$ \\
\hline & $\begin{array}{l}(-6.40 \\
6) \\
\end{array}$ & $\begin{array}{l}(-2.21 \\
4)\end{array}$ & $\begin{array}{l}(-0.96 \\
3)\end{array}$ & $\begin{array}{l}(-1.2 \\
71) \\
\end{array}$ & $\begin{array}{l}(-2.24 \\
2)\end{array}$ & $\begin{array}{l}(0.52 \\
2) \\
\end{array}$ & $\begin{array}{l}(2.02 \\
1)\end{array}$ & $\begin{array}{l}(1.70 \\
2)\end{array}$ & $\begin{array}{l}(0.42 \\
2)\end{array}$ & $\begin{array}{l}(0.57 \\
1)\end{array}$ & $\begin{array}{l}(0.10 \\
8)\end{array}$ & $\begin{array}{l}\text { (1.86 } \\
\text { 1) }\end{array}$ \\
\hline
\end{tabular}

\begin{tabular}{|c|c|c|c|c|c|c|c|c|c|c|c|c|}
\hline & \multicolumn{4}{|c|}{ Low-BM $(30 \%)$} & \multicolumn{4}{|c|}{ Middle-BM (40\%) } & \multicolumn{4}{|c|}{ High-BM $(30 \%)$} \\
\hline & $\mathrm{K}=1$ & $K=3$ & $\mathrm{~K}=6$ & $\mathrm{~K}=12$ & $\mathrm{~K}=1$ & $K=3$ & $K=6$ & $K=12$ & $\mathrm{~K}=1$ & $\mathrm{~K}=3$ & $\mathrm{~K}=6$ & $\begin{array}{l}\mathrm{K}=1 \\
2\end{array}$ \\
\hline $\begin{array}{l}S \\
1\end{array}$ & $\begin{array}{l}2.122 \\
* * *\end{array}$ & $\begin{array}{l}1.13 \\
2 *\end{array}$ & $\begin{array}{l}0.82 \\
1\end{array}$ & 0.358 & $\begin{array}{l}2.628 \\
* * *\end{array}$ & $\begin{array}{l}1.511 \\
* * *\end{array}$ & $\begin{array}{l}1.220 \\
* *\end{array}$ & $\begin{array}{l}1.133 \\
* *\end{array}$ & $\begin{array}{l}2.266 \\
* * *\end{array}$ & $\begin{array}{l}1.42 \\
0 * *\end{array}$ & 0.902 & $\begin{array}{l}0.70 \\
0\end{array}$ \\
\hline & $\begin{array}{l}(2.62 \\
2)\end{array}$ & $\begin{array}{l}\text { (1.72 } \\
2)\end{array}$ & $\begin{array}{l}(1.50 \\
1)\end{array}$ & $\begin{array}{l}(0.78 \\
7)\end{array}$ & $\begin{array}{l}(3.85 \\
2)\end{array}$ & $\begin{array}{l}(2.63 \\
8)\end{array}$ & $\begin{array}{l}(2.20 \\
0)\end{array}$ & $\begin{array}{l}(2.23 \\
2)\end{array}$ & $\begin{array}{l}(3.722 \\
)\end{array}$ & $\begin{array}{l}(2.20 \\
4)\end{array}$ & $\begin{array}{l}(1.59 \\
8)\end{array}$ & $\begin{array}{l}(1.24 \\
4)\end{array}$ \\
\hline $\begin{array}{l}S \\
2\end{array}$ & $\begin{array}{l}1.677 \\
*\end{array}$ & $\begin{array}{l}2.10 \\
2 * *\end{array}$ & $\begin{array}{l}2.12 \\
6^{* *}\end{array}$ & $\begin{array}{l}2.104 \\
* *\end{array}$ & $\begin{array}{l}1.912 \\
* *\end{array}$ & $\begin{array}{l}1.742 \\
* * *\end{array}$ & $\begin{array}{l}1.914 \\
* * *\end{array}$ & $\begin{array}{l}1.673 \\
* * *\end{array}$ & $\begin{array}{l}1.302 \\
* *\end{array}$ & $\begin{array}{l}1.20 \\
1 * *\end{array}$ & 0.921 & $\begin{array}{l}0.78 \\
5\end{array}$ \\
\hline & $\begin{array}{l}(1.87 \\
6)\end{array}$ & $\begin{array}{l}\text { (2.22 } \\
3)\end{array}$ & $\begin{array}{l}(2.39 \\
2)\end{array}$ & $\begin{array}{l}(2.42 \\
4)\end{array}$ & $\begin{array}{l}(2.32 \\
6)\end{array}$ & $\begin{array}{l}(2.82 \\
5)\end{array}$ & $\begin{array}{l}(3.22 \\
1)\end{array}$ & $\begin{array}{l}(2.86 \\
0)\end{array}$ & $\begin{array}{l}(2.122 \\
)\end{array}$ & $\begin{array}{l}\text { (2.10 } \\
3)\end{array}$ & $\begin{array}{l}(1.42 \\
0)\end{array}$ & $\begin{array}{l}(1.29 \\
7)\end{array}$ \\
\hline $\begin{array}{l}\mathrm{S} \\
3\end{array}$ & $\begin{array}{l}1.801 \\
*\end{array}$ & $\begin{array}{l}1.88 \\
0 * *\end{array}$ & $\begin{array}{l}2.10 \\
8 * *\end{array}$ & $\begin{array}{l}2.064 \\
* * *\end{array}$ & $\begin{array}{l}2.120 \\
* * *\end{array}$ & $\begin{array}{l}1.973 \\
* * *\end{array}$ & $\begin{array}{l}1.952 \\
* * *\end{array}$ & $\begin{array}{l}1.675 \\
* * *\end{array}$ & $\begin{array}{l}1.424 \\
* *\end{array}$ & $\begin{array}{l}1.10 \\
8 * *\end{array}$ & $\begin{array}{l}0.960 \\
*\end{array}$ & $\begin{array}{l}0.86 \\
9 *\end{array}$ \\
\hline & $\begin{array}{l}(1.90 \\
2)\end{array}$ & $\begin{array}{l}(2.27 \\
0) \\
\end{array}$ & $\begin{array}{l}(2.38 \\
2)\end{array}$ & $\begin{array}{l}(2.78 \\
4)\end{array}$ & $\begin{array}{l}(3.21 \\
2)\end{array}$ & $\begin{array}{l}3.29 \\
6) \\
\end{array}$ & $\begin{array}{l}(3.10 \\
8)\end{array}$ & $\begin{array}{l}(3.24 \\
0)\end{array}$ & $\begin{array}{l}(2.165 \\
)\end{array}$ & $\begin{array}{l}(1.99 \\
0) \\
\end{array}$ & $\begin{array}{l}(1.69 \\
2)\end{array}$ & $\begin{array}{l}(1.72 \\
4)\end{array}$ \\
\hline $\begin{array}{l}S \\
4\end{array}$ & $\begin{array}{l}1.884 \\
* *\end{array}$ & $\begin{array}{l}1.89 \\
8 * *\end{array}$ & $\begin{array}{l}2.11 \\
7 * *\end{array}$ & $\begin{array}{l}2.053 \\
* * *\end{array}$ & $\begin{array}{l}2.170 \\
* * *\end{array}$ & $\begin{array}{l}1.652 \\
* * \\
\end{array}$ & $\begin{array}{l}1.582 \\
* *\end{array}$ & $\begin{array}{l}1.801 \\
* * *\end{array}$ & $\begin{array}{l}0.982 \\
*\end{array}$ & $\begin{array}{l}0.68 \\
2 *\end{array}$ & $\begin{array}{l}0.482 \\
*\end{array}$ & $\begin{array}{l}0.50 \\
9^{*}\end{array}$ \\
\hline & $\begin{array}{l}\text { (2.10 } \\
9)\end{array}$ & $\begin{array}{l}(2.48 \\
1) \\
\end{array}$ & $\begin{array}{l}(2.59 \\
0) \\
\end{array}$ & $\begin{array}{l}(2.87 \\
2) \\
\end{array}$ & $\begin{array}{l}\text { (2.68 } \\
\text { 2) } \\
\end{array}$ & $\begin{array}{l}\text { (2.37 } \\
\text { 2) } \\
\end{array}$ & $\begin{array}{l}(2.21 \\
3) \\
\end{array}$ & $\begin{array}{l}3.21 \\
1) \\
\end{array}$ & $\begin{array}{l}(1.723 \\
\end{array}$ & $\begin{array}{l}(1.67 \\
0) \\
\end{array}$ & $\begin{array}{l}(1.76 \\
2) \\
\end{array}$ & $\begin{array}{l}\text { (1.69 } \\
2)\end{array}$ \\
\hline $\begin{array}{l}\mathrm{P} \\
\mathrm{M}\end{array}$ & 0.312 & $\begin{array}{l}0.37 \\
3 \\
\end{array}$ & $\begin{array}{l}0.38 \\
2\end{array}$ & $\begin{array}{l}0.623 \\
* *\end{array}$ & $\begin{array}{l}-1.82 \\
6 * *\end{array}$ & $\begin{array}{l}-0.15 \\
8\end{array}$ & 0.292 & 0.311 & -0.932 & $\begin{array}{l}-0.20 \\
1\end{array}$ & $\begin{array}{l}-0.33 \\
8\end{array}$ & $\begin{array}{l}0.21 \\
6\end{array}$ \\
\hline
\end{tabular}




\begin{tabular}{|c|c|c|c|c|c|c|c|c|c|c|c|c|}
\hline & $\begin{array}{l}(0.32 \\
1)\end{array}$ & $\begin{array}{l}(0.49 \\
5)\end{array}$ & $\begin{array}{l}(0.64 \\
1)\end{array}$ & $\begin{array}{l}(2.20 \\
6) \\
\end{array}$ & $\begin{array}{l}(-2.43 \\
3)\end{array}$ & $\begin{array}{l}(-0.27 \\
2)\end{array}$ & $\begin{array}{l}(0.89 \\
1)\end{array}$ & $\begin{array}{l}(1.20 \\
3)\end{array}$ & $\begin{array}{l}(-1.48 \\
8)\end{array}$ & $\begin{array}{l}(-0.3 \\
92)\end{array}$ & $\begin{array}{l}(-0.71 \\
2)\end{array}$ & $\begin{array}{l}(0.45 \\
2)\end{array}$ \\
\hline & \multicolumn{4}{|c|}{ Low liquidity $(30 \%)$} & \multicolumn{4}{|c|}{ Middle liquidity (40\%) } & \multicolumn{4}{|c|}{ High liquidity $(30 \%)$} \\
\hline & $\mathrm{K}=1$ & $\mathrm{~K}=3$ & $\mathrm{~K}=6$ & $\mathrm{~K}=12$ & $\mathrm{~K}=1$ & $\mathrm{~K}=3$ & $K=6$ & $K=12$ & $\mathrm{~K}=1$ & $K=3$ & $\mathrm{~K}=6$ & $\begin{array}{l}\mathrm{K}=1 \\
2\end{array}$ \\
\hline $\begin{array}{l}S \\
1\end{array}$ & $\begin{array}{l}1.499 \\
*\end{array}$ & $\begin{array}{l}1.44 \\
8 *\end{array}$ & $\begin{array}{l}1.16 \\
0\end{array}$ & 0.475 & $\begin{array}{l}1.376 \\
*\end{array}$ & $\begin{array}{l}1.151 \\
* *\end{array}$ & $\begin{array}{l}1.107 \\
*\end{array}$ & 0.660 & 0.383 & $\begin{array}{l}0.81 \\
5\end{array}$ & $\begin{array}{l}1.233 \\
* *\end{array}$ & $\begin{array}{l}1.33 \\
3 * *\end{array}$ \\
\hline & $\begin{array}{l}(1.77 \\
7) \\
\end{array}$ & $\begin{array}{l}(1.73 \\
1) \\
\end{array}$ & $\begin{array}{l}(1.23 \\
1) \\
\end{array}$ & $\begin{array}{l}(0.87 \\
0)\end{array}$ & $\begin{array}{l}(1.93 \\
2)\end{array}$ & $\begin{array}{l}(2.21 \\
9) \\
\end{array}$ & $\begin{array}{l}(2.05 \\
1)\end{array}$ & $\begin{array}{l}(1.06 \\
0)\end{array}$ & $\begin{array}{l}(0.591 \\
{ }^{2}\end{array}$ & $\begin{array}{l}\text { (1.41 } \\
1)\end{array}$ & $\begin{array}{l}(2.05 \\
1)\end{array}$ & $\begin{array}{l}\text { (2.32 } \\
6)\end{array}$ \\
\hline $\begin{array}{l}S \\
2\end{array}$ & $\begin{array}{l}1.820 \\
* *\end{array}$ & $\begin{array}{l}1.26 \\
8 * *\end{array}$ & $\begin{array}{l}1.35 \\
2 *\end{array}$ & 0.687 & $\begin{array}{l}1.621 \\
* *\end{array}$ & $\begin{array}{l}1.491 \\
* *\end{array}$ & $\begin{array}{l}1.425 \\
* *\end{array}$ & $\begin{array}{l}1.019 \\
*\end{array}$ & 0.742 & $\begin{array}{l}1.50 \\
6 * *\end{array}$ & $\begin{array}{l}1.770 \\
* * *\end{array}$ & $\begin{array}{l}1.32 \\
1 *\end{array}$ \\
\hline & $\begin{array}{l}(2.48 \\
7) \\
\end{array}$ & $\begin{array}{l}(2.06 \\
7) \\
\end{array}$ & $\begin{array}{l}(1.68 \\
1)\end{array}$ & $\begin{array}{l}(0.72 \\
7) \\
\end{array}$ & $\begin{array}{l}(1.99 \\
2) \\
\end{array}$ & $\begin{array}{l}(2.12 \\
2) \\
\end{array}$ & $\begin{array}{l}(2.29 \\
0) \\
\end{array}$ & $\begin{array}{l}(1.91 \\
0) \\
\end{array}$ & $\begin{array}{l}(1.281 \\
\end{array}$ & $\begin{array}{l}(2.26 \\
1) \\
\end{array}$ & $\begin{array}{l}(2.59 \\
8) \\
\end{array}$ & $\begin{array}{l}(1.89 \\
1)\end{array}$ \\
\hline $\begin{array}{l} \\
3\end{array}$ & $\begin{array}{l}1.721 \\
*\end{array}$ & $\begin{array}{l}1.13 \\
0 * *\end{array}$ & $\begin{array}{l}1.03 \\
5^{*}\end{array}$ & 0.732 & $\begin{array}{l}2.228 \\
* * *\end{array}$ & $\begin{array}{l}2.057 \\
* * *\end{array}$ & $\begin{array}{l}1.722 \\
* * *\end{array}$ & $\begin{array}{l}1.416 \\
* * *\end{array}$ & 1.162 & $\begin{array}{l}1.71 \\
2 * *\end{array}$ & $\begin{array}{l}2.102 \\
* * *\end{array}$ & $\begin{array}{l}1.42 \\
2 * *\end{array}$ \\
\hline & $\begin{array}{l}\text { (1.86 } \\
\text { 2) }\end{array}$ & $\begin{array}{l}(2.12 \\
2)\end{array}$ & $\begin{array}{l}\text { (1.74 } \\
7)\end{array}$ & $\begin{array}{l}(1.20 \\
5)\end{array}$ & $\begin{array}{l}\text { (2.87 } \\
\text { 2) }\end{array}$ & $\begin{array}{l}(2.67 \\
0)\end{array}$ & $\begin{array}{l}\text { (2.89 } \\
3)\end{array}$ & $\begin{array}{l}(2.65 \\
9)\end{array}$ & $\begin{array}{l}(1.622 \\
)^{2}\end{array}$ & $\begin{array}{l}\text { (2.48 } \\
\text { 2) }\end{array}$ & $\begin{array}{l}(3.20 \\
6)\end{array}$ & $\begin{array}{l}\text { (2.12 } \\
1)\end{array}$ \\
\hline $\begin{array}{l}S \\
4\end{array}$ & $\begin{array}{l}1.242 \\
*\end{array}$ & $\begin{array}{l}1.16 \\
9 *\end{array}$ & $\begin{array}{l}0.68 \\
6\end{array}$ & 0.403 & $\begin{array}{l}1.258 \\
* *\end{array}$ & $\begin{array}{l}1.001 \\
*\end{array}$ & $\begin{array}{l}0.963 \\
*\end{array}$ & 0.521 & 0.922 & $\begin{array}{l}1.50 \\
8 * *\end{array}$ & $\begin{array}{l}1.492 \\
* *\end{array}$ & $\begin{array}{l}1.01 \\
2 *\end{array}$ \\
\hline & $\begin{array}{l}\text { (1.91 } \\
7)\end{array}$ & $\begin{array}{l}(1.94 \\
1)\end{array}$ & $\begin{array}{l}(1.57 \\
7)\end{array}$ & $\begin{array}{l}(1.03 \\
8)\end{array}$ & $\begin{array}{l}(1.98 \\
1)\end{array}$ & $\begin{array}{l}(1.94 \\
7) \\
\end{array}$ & $\begin{array}{l}\text { (1.73 } \\
9)\end{array}$ & $\begin{array}{l}(0.92 \\
3)\end{array}$ & )$^{(1.447}$ & $\begin{array}{l}(1.99 \\
0) \\
\end{array}$ & $\begin{array}{l}\text { (2.43 } \\
2)\end{array}$ & $\begin{array}{l}(1.82 \\
4)\end{array}$ \\
\hline $\begin{array}{l}\mathrm{P} \\
\mathrm{M}\end{array}$ & 0.601 & $\begin{array}{l}-0.21 \\
0 \\
\end{array}$ & $\begin{array}{l}0.39 \\
8 \\
\end{array}$ & $\begin{array}{l}0.588 \\
* *\end{array}$ & $\begin{array}{l}-0.16 \\
1\end{array}$ & 0.119 & 0.261 & 0.390 & $\begin{array}{l}-2.844 \\
* * *\end{array}$ & $\begin{array}{l}-0.52 \\
3\end{array}$ & 0.187 & $\begin{array}{l}0.44 \\
2\end{array}$ \\
\hline & $\begin{array}{l}(0.39 \\
4)\end{array}$ & $\begin{array}{l}(-0.3 \\
72)\end{array}$ & $\begin{array}{l}(0.87 \\
2)\end{array}$ & $\begin{array}{l}(1.89 \\
1)\end{array}$ & $\begin{array}{l}(-0.19 \\
9)\end{array}$ & $\begin{array}{l}(0.14 \\
2)\end{array}$ & $\begin{array}{l}(0.58 \\
6)\end{array}$ & $\begin{array}{l}(1.40 \\
4)\end{array}$ & $\begin{array}{l}(-2.89 \\
3)\end{array}$ & $\begin{array}{l}(-0.7 \\
88)\end{array}$ & $\begin{array}{l}(0.39 \\
1)\end{array}$ & $\begin{array}{l}\text { (1.33 } \\
2)\end{array}$ \\
\hline
\end{tabular}

Notes: Based on the out-of-sample expected returns for four trading strategies and the momentum trading strategy (PM) in the 3-month formation period, we sort stocks into 10 groups, with group 1 containing loser stocks and group 10 containing winner stocks. We then construct a zero-cost long-short portfolio by longing winner stocks and shorting loser stocks. The portfolios are held for 1, 3, 6 and 12 months, respectively. We use the Fama-French five-factor model to obtain abnormal returns. The table reports the results for the samples excluding January, rolling 12 months, rolling 36 months prediction, different market size groups, different book-to-market ratio groups, and different liquidity groups. $* * *, * *, *$ represent the significance at the $1 \%, 5 \%$, and $10 \%$ levels, respectively. 
Table 8: Performance of the investment strategies: Standard samples of financing and securities loan (from Apr 2010 to Dec 2016)

\begin{tabular}{|c|c|c|c|c|c|c|c|c|c|c|c|c|}
\hline & \multicolumn{4}{|c|}{$\begin{array}{l}\text { best (worst) } 5 \text { num. of } \\
\text { shares }\end{array}$} & \multicolumn{4}{|c|}{$\begin{array}{l}\text { best (worst) } 10 \text { num. of } \\
\text { shares }\end{array}$} & \multicolumn{4}{|c|}{$\begin{array}{l}\text { best (worst) } 15 \text { num. of } \\
\text { shares }\end{array}$} \\
\hline & $\mathrm{K}=1$ & $K=3$ & $\mathrm{~K}=6$ & $K=12$ & $K=1$ & $\mathrm{~K}=3$ & $\mathrm{~K}=6$ & $K=12$ & $K=1$ & $\mathrm{~K}=3$ & $K=6$ & $K=12$ \\
\hline S & 0.62 & 0.80 & 0.57 & 0.63 & & & 0.63 & 0.53 & 0.83 & 1.09 & 0.84 & 0.68 \\
\hline \multirow[t]{3}{*}{1} & $1 *$ & $2 *$ & 2 & 0 & 1.194 & 0.961 & 8 & 6 & 6 & 0 & 8 & 4 \\
\hline & (1.7 & (1.8 & $(1.5$ & (1.6 & $(1.26$ & $(1.04$ & $\begin{array}{l}(0.7 \\
\end{array}$ & $(0.6$ & $(0.9$ & $(1.2$ & (1.0 & $(0.8$ \\
\hline & 71) & 86) & 93) & 06) & 3) & & 07) & 47) & 21) & 49) & 01) & 73) \\
\hline S & 1.74 & 1.61 & 1.52 & 1.93 & 2.235 & 1.721 & 1.61 & 1.85 & 2.06 & 1.56 & 1.45 & 1.77 \\
\hline \multirow[t]{3}{*}{2} & $2 *$ & $0^{*}$ & $1 *$ & $9 *$ & & & $4 *$ & $1 * *$ & $9 * *$ & $8 * *$ & $4 *$ & $2 * *$ \\
\hline & (1.8 & (1.6 & (1.7 & (1.9 & $(2.42$ & $(2.00$ & (1.8 & $(2.0$ & $(2.4$ & $(2.0$ & (1.7 & (2.11 \\
\hline & 10) & 72) & 58) & 24) & 1) & & 02) & 68) & 13) & 30) & 91) & 5) \\
\hline$S$ & 1.83 & 1.74 & 1.73 & 1.97 & 1.967 & 1.763 & 1.71 & 1.91 & 1.82 & 1.77 & 1.61 & 1.76 \\
\hline \multirow[t]{3}{*}{3} & $5 *$ & $4 *$ & $0^{*}$ & $8 *$ & $* *$ & & $5^{*}$ & $8 * *$ & $1 * *$ & $6 * *$ & $9 *$ & $5 * *$ \\
\hline & $(1.7$ & $(1.8$ & $(1.8$ & (1.8 & (2.09 & $(2.03$ & $(1.8$ & $(2.0$ & $(2.1$ & $(2.2$ & (1.9 & $(2.0$ \\
\hline & 14) & 22) & 53) & 01) & 3) & 7) & 81) & 86) & 33) & 33) & 78) & 90) \\
\hline S & 1.28 & 1.10 & 1.00 & 1.28 & & & 1.11 & 1.56 & 1.38 & 1.13 & 1.11 & 1.47 \\
\hline \multirow[t]{3}{*}{4} & $4 *$ & $3 *$ & $6^{*}$ & $2 *$ & 1.322 & 1.140 & 2 & $6^{*}$ & $2 *$ & 0 & 2 & $2 *$ \\
\hline & $(1.9$ & $(1.9$ & $(1.8$ & (1.9 & $(1.42$ & $(1.27$ & $(1.2$ & $(1.6$ & $(1.6$ & $(1.4$ & $(1.3$ & (1.7 \\
\hline & 49) & 42) & 61) & 22) & 5) & 9) & 02) & 78) & 99) & 38) & 69) & 66) \\
\hline \multirow{6}{*}{$\begin{array}{l}\mathrm{P} \\
\mathrm{M}\end{array}$} & -1.1 & 1.23 & 1.43 & 0.82 & -0.43 & & 0.92 & 0.69 & -0.6 & 0.35 & 0.43 & 0.47 \\
\hline & $20 *$ & $2^{*}$ & $3^{*}$ & $8 *$ & 3 & 0.856 & & $0 * *$ & 81 & 7 & 1 & 0 \\
\hline & $(-1.8$ & $(1.8$ & $(1.9$ & (1.9 & $(-0.3$ & $(1.06$ & $(1.6$ & $(2.0$ & $(-0.6$ & $(0.4$ & $(0.7$ & $(1.5$ \\
\hline & 21) & 61) & 17) & 23) & 94) & 2) & 18) & 84) & 70) & 51) & 89) & 00) \\
\hline & \multicolumn{4}{|c|}{$\begin{array}{l}\text { best (worst) } 20 \text { num. of } \\
\text { shares }\end{array}$} & \multicolumn{4}{|c|}{$\begin{array}{l}\text { best (worst) } 25 \text { num. of } \\
\text { shares }\end{array}$} & \multicolumn{4}{|c|}{$\begin{array}{l}\text { best (worst) } 30 \text { num. of } \\
\text { shares }\end{array}$} \\
\hline & $\mathrm{K}=1$ & $\mathrm{~K}=3$ & $\mathrm{~K}=6$ & $K=12$ & $\mathrm{~K}=1$ & $\mathrm{~K}=3$ & $\mathrm{~K}=6$ & $K=12$ & $\mathrm{~K}=1$ & $\mathrm{~K}=3$ & $\mathrm{~K}=6$ & $\mathrm{~K}=12$ \\
\hline $\mathrm{S}$ & 1.07 & 1.08 & 0.90 & 0.66 & & & 0.81 & 0.58 & 0.92 & 1.16 & 0.95 & 0.69 \\
\hline \multirow[t]{3}{*}{1} & 3 & 3 & 9 & 9 & 0.830 & 1.049 & 8 & 8 & 1 & $3 *$ & 1 & 8 \\
\hline & $(1.3$ & $(1.3$ & (1.1 & $(0.9$ & $(1.08$ & $(1.39$ & (1.1 & $(0.8$ & $(1.2$ & (1.6 & $(1.4$ & $(1.0$ \\
\hline & 25) & 36) & 66) & 29) & 5) & 2) & 08) & 63) & 73) & 58) & 14) & 98) \\
\hline$S$ & 1.93 & 1.76 & 1.57 & 1.72 & 2.065 & 1.939 & 1.72 & 1.73 & 1.86 & 1.80 & 1.69 & 1.63 \\
\hline \multirow[t]{3}{*}{2} & $6 * *$ & $0^{* *}$ & $8 * *$ & $9 * *$ & $* * *$ & $* * *$ & $8 * *$ & $5 * *$ & $5 * *$ & $3 * *$ & $1 * *$ & $8 * *$ \\
\hline & $(2.4$ & $(2.4$ & $(2.0$ & $(2.1$ & $(2.66$ & $(2.70$ & $(2.3$ & $(2.2$ & $(2.4$ & $(2.4$ & $(2.31$ & $(2.1$ \\
\hline & 03) & 26) & 75) & 57) & 6) & 5) & 53) & 31) & 24) & 94) & 1) & 30) \\
\hline $\mathrm{S}$ & 1.90 & 1.73 & 1.57 & 1.66 & 1.814 & 1.778 & 1.61 & 1.66 & 1.76 & 1.67 & 1.56 & 1.59 \\
\hline \multirow[t]{3}{*}{3} & $6 * *$ & $5^{* *}$ & $5 * *$ & $1 * *$ & $* *$ & & $6 * *$ & $3 * *$ & $7 * *$ & $0 * *$ & $3 * *$ & $3 * *$ \\
\hline & $(2.3$ & $(2.3$ & $(2.0$ & $(2.0$ & $(2.32$ & $(2.48$ & $(2.2$ & $(2.1$ & $(2.3$ & $(2.3$ & $(2.1$ & $(2.1$ \\
\hline & 83) & 35) & 65) & 97) & 6) & 3) & 09) & 61) & 63) & 61) & 83) & 20) \\
\hline S & 1.49 & 1.32 & 1.07 & 1.36 & & & 1.01 & 1.31 & 0.86 & 0.97 & 1.00 & 1.26 \\
\hline \multirow[t]{3}{*}{4} & $8 * *$ & $1 *$ & 1 & $9 *$ & 1.019 & 1.095 & 6 & $2 *$ & 5 & 6 & 5 & $7 *$ \\
\hline & $(1.9$ & (1.7 & $(1.3$ & $(1.7$ & $(1.37$ & $(1.53$ & $(1.3$ & $(1.7$ & $(1.1$ & $(1.3$ & $(1.3$ & $(1.7$ \\
\hline & 96) & 90) & 88) & 18) & 3) & & 77) & 23) & 61) & 93) & 81) & 08) \\
\hline $\mathrm{P}$ & -1.2 & -0.1 & -0.0 & 0.29 & -0.44 & & 0.05 & 0.53 & -0.3 & 0.20 & 0.10 & 0.57 \\
\hline \multirow[t]{3}{*}{$\mathrm{M}$} & 28 & 82 & 32 & 1 & 8 & 0.044 & 4 & $4^{*}$ & 46 & 9 & 9 & $8 *$ \\
\hline & $(-1.1$ & $(-0.2$ & $(-0.0$ & $(0.8$ & $(-0.4$ & $(0.05$ & $(0.1$ & $(1.6$ & $(-0.3$ & $(0.2$ & $(0.2$ & $(1.9$ \\
\hline & 99) & 29) & 60) & 89) & 37) & & 08) & 59) & 64) & 92) & 29) & 33) \\
\hline
\end{tabular}

Notes: Based on the out-of-sample expected returns for four trading strategies and the momentum trading strategy (PM) in the 3-month formation period, we short 5, 10, 15, 20, 25, 30 stocks with the worst performance, long 5, 10, 15, 20, 25, 30 stocks with the best performance. The portfolios are held for 1, 3,6 and 12 months, respectively. We use the Fama-French five-factor model to obtain abnormal returns. ***, **, * represent the significance at the $1 \%, 5 \%$, and $10 \%$ levels, respectively. 


\section{Appendix}

\section{Table A1: The rates of return after adjusting the risks of investment strategies (additional results)}

Notes: The performance of the investment strategies examined on Table 6 are further tested using 1-month (Panel A) and 12-month (Panel B) formation periods.

$* * *, * *, *$ represent the significance at the $1 \%, 5 \%$, and $10 \%$ levels, respectively.

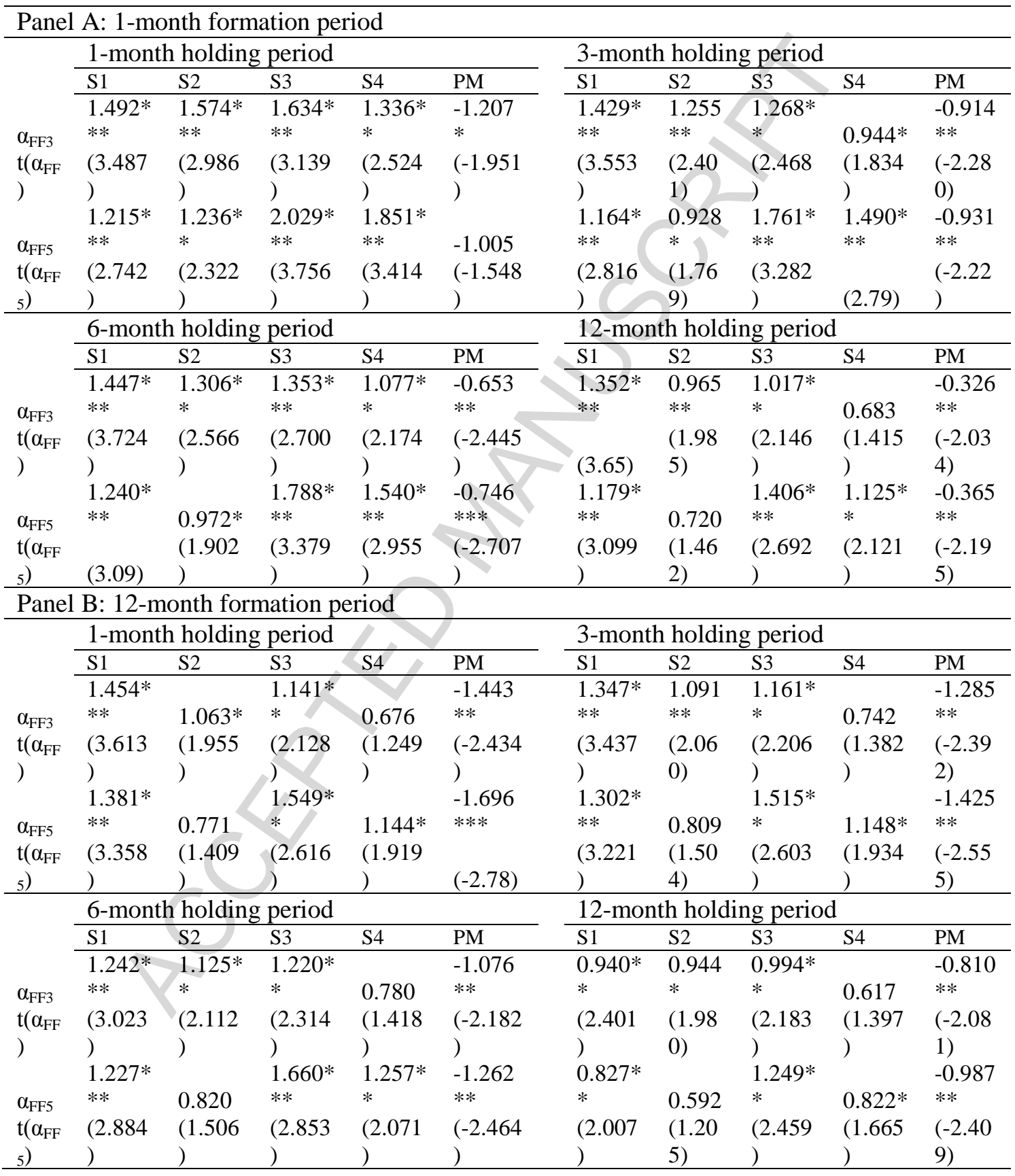




\section{Highlights}

- In- and out-of-sample tests are conducted on the cross-sectional stock return in China.

- Arbitrage risk is decomposed into noise trader risk, trading cost and information uncertainty.

- These risk components effectively forecast stock returns.

- These risk components can be used to construct portfolios with abnormal returns. 